\title{
REVISITANDO A TEORIA DA PESSOA JURÍDICA NA OBRA DE J. LAMARTINE CORRÊA DE OLIVEIRA*
}

\author{
Por Rodrigo Xavier Leonardo $* *$
}

RESUMO: Aborda-se neste ensaio o conceito de pessoa jurídica, analisando as principais teorias desenvolvidas a respeito do assunto e as consequiências para a chamada "dupla crise da pessoa jurídica". Adota-se como premissa uma investigação do pensamento do Professor José Lamartine Correa de Oliveira em suas principais obras dedicadas a este tema para refletir sobre a atualidade da contribuição teórica deste autor para o tema.

Palavras-chave: Conceito de pessoa jurídica; desconsideração da pessoa jurídica; teoria da ficção; teoria da realidade.

\section{INTRODUÇÃO}

O tema pessoa jurídica imantou as aspirações teóricas de José Lamartine Corrêa de Oliveira por quase duas décadas.

\footnotetext{
* Artigo vencedor do primeiro lugar no Concurso de Monografias Prêmio José Lamartine Corrêa de Oliveira promovido pela Ordem dos Advogados do Brasil, Seção do Paraná, no ano de 2005.

** Professor adjunto de Direito Civil nos cursos de graduação e pós-graduação da UFPR. Mestre e Doutor em Direito Civil pela USP.

$<$ www.rodrigoxavierleonardo.com.br>.
}

ABSTRACT: It is addressed in this essay the legal entity concept, analyzing the main theories developed regarding the subject and the consequences for what is known as "double legal entity crisis". It is adopted as premise an investigation of the thought of the Professor José Lamartine Correa de Oliveira in his main work dedicated to this theme in order to reflect about the actuality of the theoretically contribution of this author to the theme.

Keywords: legal entity concept; disregard of corporate entity; fiction theory; reality theory.

Foi no arco temporal entre 1962 (ano de apresentação de sua tese para concurso de livre-docência, intitulada Conceito da pessoa jurídica) e 1979 (ano de publicação de seu livro intitulado a Dupla crise da pessoa jurídica ${ }^{l}$ ) que o então professor titular de direito civil da UFPR dedicou todo o seu incomum talento para penetrar e desbastar uma selva teórica que neste país permanecia inóspita e, nalguma medida, intocada.

\footnotetext{
${ }^{1}$ CORRÊA DE OLIVEIRA, J. Lamartine. A dupla crise da pessoa jurídica. São Paulo: Saraiva, 1979.
} 
A dimensão desse gigantesco trabalho de deslinde e de assentamento de marcos miliares, todavia, não pode ser aquilatada sem uma breve retrospecção histórica. Naqueles anos, o pesquisador que desejasse estudar a temática da pessoa jurídica estaria numa situação contraditoriamente difícil.

Ao olhar para fora, autoridades do direito privado europeu sentenciavam o problema conceitual da pessoa jurídica a um debate do século XIX, palco de discussões apaixonadas que renderam uma produção assombrosa, seja do ponto de vista quantitativo, seja do ponto de vista da verticalidade teórica.

Riccardo Orestano escreveu que apenas ao final do século XVIII e início do século XIX é que a pessoa jurídica passou a ser teorizada sob a sustentação subjetivista segundo a qual os "direitos e obrigações" seriam reservados ao sujeito de direito, entendido este como o potencial titular de direitos subjetivos referenciados pelo natural poder de vontade. ${ }^{2}$

Ao olhar para dentro (e aí estava a contrariedade) praticamente inexistiam estudos monográficos na doutrina jurídica nacional, o que justificava uma investigação universitária, em moldes científicos, a respeito do assunto em direito brasileiro. ${ }^{3}$

\footnotetext{
${ }^{2}$ ORESTANO, Riccardo. Il < problema delle persone giuridiche> in diritto romano. Torino: Giappichelli, 1968 , p.17 et seq. Não se desconsideram os estudos e as preocupações teóricas em períodos precedentes, sobretudo a partir dos canonistas do século XIII em diante. Compreende-se, entretanto, que apenas no século XIX surge o desafio de inserir aquelas organizações num 'sistema' que passava a girar ao redor das noções de sujeito de direito e de direito subjetivo, concebidas segundo o antropocentrismo individualista jusnaturalista. Sobre o assunto, cf. GIERKE, Otto Von. Political theories of the middle age. trad. Frederic William Maitland. Boston: Beacon Press, 1958, p. 67 e seq.

${ }^{3}$ Com justificadas ressalvas, dentre outras, para as importantes obras de Lacerda de Almeida (LACERDA
}

Sob essas circunstâncias, na tese escrita em 1962, Lamartine enfrentou o tema do conceito de pessoa jurídica, justificando sua preocupação, como teórico do século XX. ${ }^{4}$ Essa tese serviu de base para, dezessete anos mais tarde, ser lançado o livro sobre a dupla crise da personalidade jurídica, por meio do qual o autor atou as perspectivas teóricas e prático-forenses, conjugando seu brilho de acadêmico com seus esforços de advogado militante.

Ao dissertar sobre a dupla vicissitude da pessoa jurídica, Lamartine apresentou soluções inéditas para a crise do reconhecimento e para a crise de função deste instituto. Enfrentou, assim, o problema da desconsideração da pessoa jurídica - apresentada ao Brasil, inicialmente, por outro ilustre advogado e professor paranaense $\mathrm{e}^{5}$ - e brindou o direito nacional com um aprimoramento da técnica jurídica espiritualizada por um humanismo marcante.

DE ALMEIDA, Francisco de Paula. Das pessoas jurídicas: ensaio de uma theoria. Rio de Janeiro: Revista dos Tribunais, 1905) e Ernani Guarita Cartaxo (CARTAXO, Ernani Guarita. As pessoas jurídicas em suas origens romanas. Curitiba: Empreza Gráfica Paranaense, 1943).

${ }^{4}$ Ao justificar o estudo da pessoa jurídica, o Prof. J. Lamartine Corrêa de Oliveira lança advertência prévia: "Sua importância. É enorme. Provoca uma reflexão em torno do conceito de direito subjetivo e das próprias noções fundamentais do Direito. Revela a posição do autor, o ângulo em que se situa, no plano filosófico, e sociológico. Por outro lado, está tão intimamente ligado ao problema da personalidade humana, que de seu exato equacionamento pende uma correta solução do problema das relações entre o Estado e os grupos intermediários existentes na sociedade, de um lado, e entre todas as realidades coletivas e o ser humano, por outro". (CORREAA DE OLIVEIRA, J. Lamartine. Conceito de pessoa jurídica, p. 5).

${ }^{5}$ REQUIÃO, Rubens. Abuso de direito e fraude através da personalidade jurídica. Revista dos Tribunais, a. 58 , v. 410 , dez./1969, p. 12-24. 
Entre o Conceito de pessoa jurídica e a Dupla crise da personalidade jurídica existe todo um caminho a repercorrer para a compreensão do pensamento inovador de J. Lamartine Corrêa de Oliveira. No presente ensaio, busca-se reconstruir este caminho, de modo a justificar as razões pelas quais reler a obra desse jurista é indispensável para compreender a problemática da pessoa jurídica no século XXI.

\section{O CONCEITO DE PESSOA JURÍDICA}

No início da década de 1960, a doutrina privatista conjugava uma infinidade de teorias voltadas a definir a pessoa jurídica, seguidas de inúmeras outras subteorias que buscavam sua parcela de verdade nesta seara. Francesco Ferrara, muito antes, já apontara a formação de "uma literatura extraordinariamente rica e variada, na qual figuram os melhores nomes do mundo jurídico, cuja organização em teorias autônomas apresenta singular dificuldade" . Estava dado o primeiro desafio a ser superado na construção da tese sobre o conceito da pessoa jurídica. Não bastava descrever as inúmeras teorias para posterior posicionamento a respeito. $\mathrm{O}$ assunto carecia de ordenação crítica.

Para tanto, J. Lamartine Corrêa de Oliveira elegeu dois critérios distintivos para as diversas teorias. O primeiro deles diferenciava as teorias mediante a visão de sociedade dos diversos doutrinadores, especificamente quanto ao reconhecimento dos agrupamentos sociais. O segundo critério pautava-se pela concepção de direito subjetivo subjacente a cada uma das teorias

${ }^{6}$ FERRARA, Francesco. Teoria delle persone giuridiche. 2. ed. riveduta. Napoli: Marghieri, 1923, p. 133. voltadas a explicar a natureza das pessoas jurídicas. Os dois critérios refletem algumas das mais importantes posições filosóficas do nosso autor.

Ao eleger a visão da sociedade como um dos divisores entre teorias da pessoa jurídica, o estudioso procurava destacar a necessidade de distinguir teorias jurídicas centralizadas na norma jurídica das demais doutrinas que procuravam soluções jurídicas com maior aderência à realidade social. ${ }^{7}$ Por outro lado, ao alertar para a concepção de direito subjetivo subjacente a cada uma das teorias, ao mesmo tempo, expressava a advertência teórica de uma prestigiosa doutrina ${ }^{8}$ e abria o campo para que as premissas jusnaturalistas, eleitas pelo autor como corretas, iluminassem suas conclusões. ${ }^{9}$

Seguindo esses critérios, ficavam inovativamente reagrupadas as teorias sobre o conceito de pessoa jurídica: doutrinas individualistas, doutrinas da existência das realidades coletivas e doutrinas normativistas, ${ }^{10}$

${ }^{7}$ CORRÊA DE OLIVEIRA, Conceito de pessoa jurídica, p.24.

${ }^{8}$ Enneccerus e Nipperdey advertiram: "El problema de la personalidad jurídica tiene estrechísima conexión con el del derecho subjetivo" (ENNECCERUS, Ludwig; NIPPERDEYM Hans Carl. Derecho civil (parte general). In: ENNECCERUS-KIPP-WOLF. Tratado de derecho civil. v.I. Barcelona: Bosch, 1954, p.421).

9 “ “(...) o Direito Positivo não deve jamais contrariar os preceitos jurídico-morais ditados pela natureza das coisas e constitutivos do direito natural. Não deve, mas é possível que contrarie, pois é possível existirem leis injurídicas, como é possível também que grupos sociais inteiros, através de longa involução histórico-social, afastar temporariamente a sua moralidade social da moral natural e do Direito Natural. Seria o caso de uma injuricidade em sentido absoluto das leis." (CORRÊA DE OLIVEIRA, J. Lamartine. Intervenção do estado no direito contratual. Curitiba, 1962, p. 38) (mimeo).

${ }^{10}$ CORRÊA DE OLIVEIRA, Conceito de pessoa jurídica, p.28. 
cujas linhas gerais apresentam-se a seguir mediante a exposição dos seus principais autores.

\subsection{As doutrinas individualistas e o antropocentrimo no direito privado moderno}

Com as 'teorias individualistas' da pessoa jurídica, J. Lamartine Corrêa de Oliveira procurou ordenar as doutrinas que reservavam exclusivamente ao ser humano a verdadeira personalidade e capacidade jurídicas. Justamente por centralizar a real subjetividade do fenômeno jurídico na pessoa humana, estas teorias são chamadas "individualistas".

Dentre essas doutrinas, destaca-se a chamada teoria da ficção, que teve como um dos seus principais expoentes Savigny, defensor do voluntarismo que marcou o pensamento pandectista do século XIX. ${ }^{11}$ Para Savigny, "o conceito primitivo de pessoa, ou seja, de sujeito de direito, deve coincidir com o conceito de homem, e esta primitiva identidade dos dois conceitos pode ser expressa com a seguinte fórmula: qualquer ser humano, e apenas o ser humano,

${ }^{11}$ Alguns autores defendem que as verdadeiras origens do pensamento ficcionista seria encontrada nos autores canonistas. Neste sentido, cf.TOBEÑAS, José Castán. Derecho civil Español. 8.ed. Madrid: Instituto Editorial Reus, 1952, p.271. Outros destacam que os fundamentos e os propósitos dessas teorias pertencem a momentos tão diversos da história do direito que não permitiriam suprimir da teoria da ficção os traços próprios à modernidade. Nesse sentido, DÍEZ-PICAZO, Luis; GULLÓN, Antonio. Instituciones de derecho civil. 2. ed. Madrid: Tecnos, 2000, p. 347 e NICOLÓ, Angela Maria Punzi. La persona giuridica in diritto canonico. In: PEPPE, Leo (org.). Persone giuridiche e storia del diritto. Torino: Giapichelli, 2004, p. 100. tem capacidade de direito". ${ }^{12}$ Ora, na medida em que qualquer direito subjetivo tem fundamento na liberdade moral intrínseca ao homem, a partir de sua potencial expressão de vontade, apenas o ser humano seria dotado de autêntica capacidade.

A despeito desses pressupostos, a ciência do direito não poderia simplesmente ignorar a existência e a importância dos agrupamentos humanos que, desde remotos tempos, agem em sociedade com autonomia. Para evitar uma contradição lógica insuperável, Savigny constrói a teoria da ficção, segundo a qual a pessoa jurídica seria fruto de uma extensão do conceito de pessoa ${ }^{13}$ efetuada pela lei.

Assim como a lei poderia, supostamente, abolir a personalidade de seres humanos que naturalmente a deteriam (como no caso do escravo), a mesma lei poderia estender, artificialmente, a personalidade a certos agrupamentos humanos mediante um ato de concessão Estatal. ${ }^{14}$ Por essa razão, esclarece que "a capacidade jurídica foi por nós demonstrada como coincidente com o conceito de ser humano. Nós a consideramos também como extensiva aos sujeitos artificiais criados por simples ficção. Tais sujeitos são por nós denominados 'pessoa jurídica". ${ }^{15}$ Verificam-se, nesse pensamento,

${ }^{12}$ SAVIGNY, Federico Carlo Di. Sistema del diritto romano attuale. trad. Vittorio Scialoja. v.II. Torino: Unione tipografico editrice, 1888, p. 2.

${ }^{13}$ SAVIGNY, Sistema del diritto romano attuale, p. 2.

${ }^{14}$ Segundo Savigny, para a personificação dos agrupamentos humanos "è necessaria l'autorizzazione del potere sovrano dello Stato". (SAVIGNY, Sistema del diritto romano attuale, p. 277).

${ }^{15}$ SAVIGNY, Sistema del diritto romano attuale, p.240. Não se pode ignorar a advertência de influentes 
o individualismo, pela negação das realidades sociais coletivas, e o voluntarismo, pela justificação dos direitos subjetivos pela expressão da vontade, ${ }^{16}$ resultando numa concepção artificial de pessoa jurídica.

A objeção de J. Lamartine Corrêa de Oliveira à teoria ficcionista é dupla. $\mathrm{O}$ voluntarismo inerente à noção de direito subjetivo é repudiado por Lamartine que, seguindo Ihering, ${ }^{17}$ aduz que "a doutrina do Wollendürfen está hoje totalmente superada e leva à absoluta inexplicabilidade o caso dos loucos e dos menores impúberes"18. Ademais, "o velho vício do individualismo, de só enxergar duas realidades na sociedade, as realidades extremas - indivíduo e Estado - encontra

privatistas que defendem que a noção fictiva da pessoa jurídica, no pensamento de Savigny, teria sido desvirtuada pela doutrina contemporânea. Massimo Bianca, partindo de Werner Flume, atesta que "sarebbe un fraintendimento attribuire al Savigny la tesi della finzione, dato che il Savigny non ebbe a fingere che la persona giuridica sia un essere umano" (BIANCA, Massimo. Diritto civile.v.I. 2.ed. Milano : Giuffrè, 2002, p.323, nota 3).

${ }^{16}$ Karl Larenz relembra Ernst Wolf e esclarece esta ligação: "Wolf considera un contrasentido la equiparación jurídica de una asociación o una organización con una persona en uno de los aspectos, esto es, en que es pensada como juridicamente capaz, como posible sujeto de derechos y obligaciones, ya que - según su definición del derecho subjetivo como competencia para la decisón solo los individuos en particular poderían ser <sujetos de derecho>". (LARENZ, Karl. Derecho civil: parte general. Madrid: Editorial Revista de Derecho Privado, 1978, p.168)

17 "Si la voluntad fuese el objeto del derecho, ¿cómo vendrian a tener derecho las personas sin voluntad? ¿Serian derechos que mentirian á su fin y á su destino? ¿Anteojos en manos de los ciegos?" (IHERING, Rudolf Von. El espíritu del Derecho Romano. t.I. Granada: Comares, 1998, p. 1028).

${ }^{18}$ CORRÊA DE OLIVEIRA, Conceito de pessoa jurídica, p. 33. magnífica acolhida em tal doutrina" 19 que, em última análise, deixaria os grupos intermediários reféns da arbitrariedade estatal pelo sistema da concessão que lhe é decorrente.

Há, ainda, outras vertentes individualistas, como a de Vareilles-Sommières - para quem a pessoa jurídica seria uma ficção doutrinária ${ }^{20}$-; aquela em que a pessoa jurídica não seria uma pessoa, mas um patrimônio destinado a um fim (Brinz, Bekker e Bonelli21), e a teoria de Ihering, segundo a qual, na pessoa jurídica, os titulares da personalidade seriam os destinatários, os verdadeiros interessados em seus benefícios ou em suas ações. ${ }^{22}$ Herdeiros desta tradição do direito privado europeu, Orlando Gomes aproxima-se da teoria da ficção doutrinária ${ }^{23}$ e o professor Alfredo de Assis Gonçalves Neto da teoria da ficção legal. ${ }^{24}$

${ }^{19}$ CORRÊA DE OLIVEIRA, Conceito de pessoa jurídica, p.37.

${ }^{20}$ Para o Marquês de Vareilles-Sommières é equivocado dizer que a pessoa jurídica é uma criação da lei, pois 'La personnalité civile, n'est pas l'oeuvre spontanée d'un artiste; ele est l'ouevre d'un grand artiste: de tout le monde", assim, "La personnalité morale ne peut être rationnellement qu'une fiction doctrinale, excellente pour exprimer, résumer et peindre vivement un certain régime social, régime qui n'est du reste nullement légal et que toutes les associations peuvent librement adopter". (VAREILLES-SOMMIÈRES, Marquis De. Les personnes morales. Paris : LGDJ, 1919, p. 26-27).

${ }^{21}$ Citados por CORRÊA DE OLIVEIRA, Conceito de pessoa jurídica, p. 37.

${ }^{22}$ Para Rudolf Von Ihering: "Los verdaderos sujetos del derecho, no son las personas jurídicas, sino los miembros aislados; aquéllas no son más que la forma especial mediante la cual éstos manifiestan sus relaciones jurídicas al mundo exterior" (IHERING, El espíritu del Derecho Romano, p.1045).

${ }^{23}$ GOMES, Orlando. Introdução ao direito civil. 6.ed. Rio de Janeiro: Forense, 1979, p. 213-214.

${ }^{24} \mathrm{Com}$ a ressalva de que a ficção, para Assis Gonçalves, seria fruto do ordenamento jurídico e não da 
Todas essas teses, sob a lente de J. Lamartine Corrêa de Oliveira, ressaltam um vício de origem: negar a existência real dos agrupamentos intermediários entre o Estado e o indivíduo. Algumas delas, como visto, carregam o agravante do voluntarismo. Nenhuma delas, na visão deste autor, conseguiria explicar a natureza da pessoa jurídica.

\subsection{As doutrinas que afirmam a existência de realidades coletivas}

Em suas primeiras formulações, as teorias realistas foram marcadas pelas premissas organicistas, alcançando seu apogeu com Otto von Gierke, cujas obras, Das Deutsche Genossenschaftsrecht (O direito alemão das associações) e Deutsches Privatrecht (Direito Privado Alemão), são consideradas um divisor de águas na teoria da pessoa jurídica. Gierke sustentava que as associações seriam entidades vivas, dotadas de realidade, independência e de uma vontade consciente que justificaria a capacidade para agir distinta de seus membros..$^{25}$ Mais do que o produto de uma simples soma de seus integrantes, essas

lei, cf. GONÇALVES NETO, Alfredo de Assis. Lições de direito societário. São Paulo: Juarez de Oliveira, 2002, p. 17-18.

${ }^{25}$ Segundo explica George Heiman, para Gierke "the association, or group, is a living entity characterized by the relationship between the unity of the whole and the multiplicity of its parts. The relationship is guided by the manifestations of the human will, and an ability to act that are distinct from the lives and wills of its individual members. Thus group-life exists side by side with individual life, not divided into a separete sphere, but inextricably bond to it. An organic tie links the two entities, a tie that is as basic and fundamental as life itself". (HEIMAN, George. The nature of associations and fellowships. In: GIERKE, Otto von. Association and law: the classical and early christian stages. trad. George Heiman. Toronto: Toronto Press, 1977, p. 7). organizações conformariam uma realidade autônoma supra-individual ${ }^{26}$.

Ao contrário do que pode parecer, não é correto asseverar uma pura e simples contraposição teórica entre o ficcionismo de Savigny e o realismo de Gierke. Entre eles existe antes uma forte coincidência. Ambos foram importantes pensadores da escola histórica do direito alemão e, desse modo, opositores do jusnaturalismo, que não apenas negava personalidade às associações, como também as combatia com veemência. ${ }^{27}$

Nessa mesma escola, porém, Savigny e Gierke ocuparam lugares opostos. Savigny esteve à frente da chamada corrente romanista da escola histórica, cujo principal escopo era investigar a matéria jurídica preestabelecida pelo direito romano para sistematizá-la ao uso do povo alemão. Gierke foi um dos expoentes da chamada corrente germanista, que buscava apreender os aspectos históricos particulares do direito germânico, visando construir uma ciência do direito nutrida pela tradição desse povo. ${ }^{28}$

No Brasil, Lacerda de Almeida e Carvalho Santos defenderam a tese organicista para

\footnotetext{
${ }^{26}$ Para Gierke, nas associações "Itself can will, itself can act, in the same way that they will and act. When 100 persons unite to form a group wich wills and acts as one, we must say that there is a real new person present - the hundred and first person, the super-person (...) Behind the legal Group-person there is therefore a real Grooup-being, just as there is a real individual human being behind the individual legal person". (Apud BAKER, Ernest. Translator's introduction. In: GIERKE, Otto von. Natural law and the theory of society 1500 to 1800. trad. Ernest Barker. Boston: Beacon Press, 1957, p. LXVI-LXVII).

${ }^{27}$ Sobre a aversão do pensamento jusnaturalista contra as associações, cf. DUGUIT, León. Traité de droit constitutionel. 12. ed. v. V. Paris: Anciene Librairie, 1925 , p. 615 et seq.

${ }^{28}$ WIEACKER, Franz. História do direito privado moderno. 2.ed. Lisboa: Calouste Gulbekian, 1993, p.430.
} 
explicação da natureza da pessoa jurídica. ${ }^{29}$ Clóvis Bevilaqua filiou-se às teorias que afirmavam a realidade da pessoa jurídica, não apresentando, todavia, com clareza, os traços organicistas. ${ }^{30}$

Ao enfrentar o pensamento de Gierke, J. Lamartine Corrêa de Oliveira destaca os avanços que essa teoria propiciou: “com exatidão, Gierke afirmou a realidade dos grupos humanos e nesse sentido sua concepção representa um progresso relativamente à doutrina da concessão estatal da personalidade" ${ }^{31}$. O voluntarismo e o organicismo do autor alemão, todavia, são severamente criticados, na exata medida em que Lamartine negava a noção voluntarista de direito subjetivo: "A famosa vontade coletiva é insuficiente para explicar a autonomia jurídica dos grupos. (...) a volição coletiva não é explicável através do organicismo" ${ }^{32}$.

Sublinhe-se que o posicionamento do autor sobre a teoria gierkeana é fiel aos dois pressupostos, por ele eleitos, para a análise e ordenação das diversas doutrinas. Se, pela perspectiva da visão de sociedade, havia um avanço, pela perspectiva do direito subjetivo, a teoria de Gierke sucumbia ao voluntarismo.

${ }^{29}$ LACERDA DE ALMEIDA. Das pessoas jurídicas: ensaio de uma theoria, p. 47-48; CARVALHO SANTOS, J. M. de. Código civil brasileiro interpretado. v. I. 4. ed. Rio de Janeiro: Freitas Bastos, 1950, p. 344.

${ }^{30}$ BEVILAQUA, Clóvis. Teoria geral do direito civil. Rio de Janeiro: Editora Rio e Livraria Francisco Alves, 1975, p. 129. Conferir, ainda, BEVILAQUA, Clóvis. O projecto de código civil e o Sr. Dr. Coelho Rodrigues. In: Projecto do codigo civil brazileiro. Rio de Janeiro: Imprensa nacional, 1902, p. 294-295.

${ }^{31}$ CORRÊA DE OLIVEIRA, Conceito de pessoa jurídica, p. 64.

${ }^{32}$ CORRÊA DE OLIVEIRA, J. Lamartine. Conceito de pessoa jurídica, p.65.
A despeito dessas críticas, a obra de Gierke abriu caminho para outras doutrinas realistas particularmente importantes para o conceito de pessoa jurídica na obra de Lamartine, cujas linhas gerais serão tratadas em tópico especial.

\subsection{O normativismo e a pessoa como centro de imputação}

Pelo grupo de doutrinas chamado normativista, J. Lamartine Corrêa de Oliveira procurou ordenar e sumariar o pensamento que buscava solucionar a questão da pessoa jurídica mediante simples recurso ao direito positivo. Sob esse pressuposto e sob a redução do direito positivo ao direito do Estado, o normativismo, em termos gerais, pretendia alcançar um conceito de pessoa jurídica depurado de elementos metajurídicos.

Um dos expoentes dessa doutrina, Francesco Ferrara, identificava três significados principais para a palavra pessoa: o significado físico-antropológico (homem); o significado teológico-filosófico (o ente racional, consciente, capaz de querer) e o significado jurídico, funcionalizado ao direito. Para se alcançar o conceito jurídico de pessoa seria necessário adotar a "exigência metodológica de não misturar estes diversos significados e utilizar para fins jurídicos conceitos e princípios que lhes são estranhos" ${ }^{\text {33. }}$.

Exatamente por isso, para os autores normativistas, o debate sobre a natureza da pessoa jurídica, ou se esses agrupamentos seriam uma ficção ou uma realidade, é falso em si mesmo. A realidade ou a ficção, expressou Pontes de Miranda ao escrever

${ }^{33}$ FERRARA, Teoria delle persone giuridiche, p. 342 . 
sobre o assunto, é algo pertinente ao suporte fático, e tanto a pessoa física como a pessoa jurídica pressupõem um suporte fático no qual a norma incide. ${ }^{34}$

O estudo e a análise dessa linha de discurso jurídico interessaram particularmente a $\mathrm{J}$. Lamartine Corrêa de Oliveira. Em toda sua obra, é enfatizada uma preocupação com a tendência normativista no Brasil, não sendo poupados críticas e esforços ao seu combate. Na qualidade de paraninfo da turma de bacharéis em direito da UFPR do ano de 1965, asseverou "sabeis que não creio no positivismo jurídico nem nos seus herdeiros mais modernos, os tecnicismos (...). Não creio numa separação artificial entre Moral e Direito. (...) a ordem jurídica deverá estar baseada em princípios de natureza ética" ${ }^{35}$.

$\mathrm{O}$ ápice do normativismo ${ }^{36}$ é alcançado na teoria pura do direito formulada por Hans Kelsen. Nessa teoria - vazada em concepções particulares sobre o direito subjetivo, dever jurídico e sujeito de direito -, o jurista

${ }^{34}$ PONTES DE MIRANDA, Francisco Cavalcanti. Tratado de Direito Privado. v. I. Rio de Janeiro: Borsoi, 1954 , p. 281 e 316, respectivamente.

${ }^{35}$ CORRÊA DE OLIVEIRA, J. Lamartine. Lição de resistência. Discurso de paraninfo aos Bacharéis em Direito de 1965 da Universidade Federal do Paraná, turma Ministro Alvaro Ribeiro da Costa (mimeo).

${ }^{36}$ Outro viés normativista que ganhou maior espaço posteriormente à obra de J. Lamartine Corrêa de Oliveira foi o chamado positivismo de linguagem, tributável à filosofia analítica. Sobre essa perspectiva, cf. D'ALESSANDRO, Floriano. Persone giuridiche $e$ analisi del linguaggio. Padova: Cedam, 1989; GALGANO, Francesco. Struttura logica e contenuto normativo del concetto di persona giuridica. Rivista di diritto civile. a. XI, n.6, Padova, Cedam, nov-dic, 1965, p.565; ZATTI, Paolo. Persona giuridica $e$ soggettività. Padova : Cedam, 1975. No Brasil, segue esta orientação JUSTEN FILHO, Marçal. Desconsideração da personalidade societária no direito brasileiro. São Paulo: Revista dos Tribunais, 1987. austríaco propõe uma reconstrução do conceito de pessoa e de pessoa jurídica. Para tanto, esvazia-se a noção de direito subjetivo ao representá-lo como um mero reflexo do dever jurídico: "Esta situação, designada como < direito $>$ ou $<$ pretensão $>$ de um indivíduo, não é, porém, outra coisa senão o dever do outro ou dos outros indivíduos" ${ }^{37}$.

Deste modo, Kelsen conclui ser o direito subjetivo noção supérflua para uma descrição científica: "Este conceito de um direito subjetivo que apenas é o simples reflexo de um dever jurídico, isto é, o conceito de um direito reflexo, pode, como conceito auxiliar, facilitar a representação da situação jurídica" ${ }^{38}$.

O dever jurídico, por sua vez, teria intrínseca identidade com a norma jurídica, tendo por conteúdo a conduta de um indivíduo, vez que "a afirmação: um indivíduo é juridicamente obrigado a uma determinada conduta, é idêntica à afirmação: uma norma jurídica prescreve aquela conduta determinada de um indivíduo", e sendo assim, o "conteúdo de um dever jurídico é normalmente a conduta de um indivíduo apenas. Mas também o pode ser a conduta de dois ou mais indivíduos. ${ }^{39}$

Se a noção de direito subjetivo é supérflua, sendo mero reflexo do dever jurídico, por razões lógicas isto deve conduzir a uma redefinição da noção de sujeito de direito. Kelsen afirma, pois, que o sujeito de direito é o sujeito de um dever jurídico, de uma conduta devida. A tradicional noção de sujeito de direito, pela perspectiva subjetivista ou

${ }^{37}$ KELSEN, Hans. Teoria pura do direito. 4.ed. Trad. João Baptista Machado. Coimbra: Armênio Amado, 1976, p.186.

${ }^{38}$ KELSEN, Teoria pura do direito, p.187.

${ }^{39}$ KELSEN, Teoria pura do direito, p.171-173. 
objetivista, seria tão prescindível quanto a noção de direito subjetivo e, igualmente, representaria a velha ideologia jusnaturalista.

Sob esses fundamentos, a teoria pura do direito procura afastar qualquer relação entre a noção natural de pessoa e a pessoa jurídica, e argumenta que tanto a pessoa física como a chamada pessoa jurídica resultariam de uma construção artificial da ciência jurídica que busca algo de uno para imputar os deveres jurídicos. O que se costuma compreender por pessoa natural contraposta à pessoa jurídica é falso: ambas são pessoas jurídicas como produto de um dever ser.

A pessoa jurídica, nesse sentido, seria apenas e tão-somente um centro de imputação autônomo de deveres jurídicos. Se os deveres jurídicos, por sua vez, têm por conteúdo uma conduta prescrita, em última análise, os deveres das pessoas jurídicas atingem o indivíduo nominado nos estatutos como responsável por esta conduta. Para Kelsen, “(...) quando a ordem jurídica estadual impõe deveres ou estabelece direitos que são considerados como deveres e direitos de uma corporação (...) apenas se pode tratar de deveres cujo cumprimento ou violação é operada através da conduta de indivíduos" ${ }^{\prime 4}$.

Em síntese. Por meio de uma cadeia lógica, Kelsen reduz as noções de direito subjetivo e de sujeito de direito à sua análise do dever jurídico, intrinsecamente ligado à norma jurídica. Essa progressiva redução do fenômeno estudado permite identificar uma destacada proximidade entre a teoria pura e o pensamento ficcionista, porquanto, ainda que a pessoa jurídica fosse considerada uma unidade autônoma, em última análise os deveres jurídicos a ela imputados atingiriam

\footnotetext{
${ }^{40}$ KELSEN, Teoria pura do direito, p. 250.
}

apenas os indivíduos nomeados nos estatutos (que nada mais seriam senão um ordenamento jurídico, em ponto pequeno, constituído de acordo com o direito objetivo).

A objeção de J. Lamartine Corrêa de Oliveira às correntes normativistas é proporcional ao grau de limitação à norma jurídica adotado em cada doutrina. No que diz respeito ao pensamento kelseniano, por exemplo, a crítica é contundente: “(...) criar o Direito numa torre de marfim, separado das realidades econômicas e sociais, pretender para a ciência jurídica total autonomia, e seu desligamento de tudo o que é 'ideológico' é intento, quando não inalcançável, absurdo e, paradoxalmente, antijurídico" ${ }^{41}$.

Tampouco aceita qualquer possibilidade de negação (León Duguit) ou de reconfiguração puramente normativa (Hans Kelsen) da noção de direito subjetivo. Isto fere os pressupostos jusnaturalistas adotados pelo autor. Neste aspecto, por exemplo, a crítica a outros autores classificados como normativistas (como, v.g., Francesco Ferrara e Pontes de Miranda) é menos intensa do que a desferida contra Hans Kelsen.

No Brasil, o normativismo teve $\mathrm{e}^{42}$ e tem ${ }^{43}$ sensível acolhida, mediante construções que

${ }^{41}$ CORRÊA DE OLIVEIRA, Conceito de pessoa jurídica, p. 95.

${ }^{42}$ Citem-se, dentre outros autores contemporâneos a Lamartine com traços normativistas, PEREIRA, Caio Mario da Silva. Instituições de direito civil. 5.ed. Rio de Janeiro: Forense, 1976, p.266; COMPARATO, Fábio Konder. O poder de controle na sociedade anônima. São Paulo: Saraiva, 1976, p. 290; BARROS MONTEIRO, Washington de. Curso de direito civil: parte geral. São Paulo: Saraiva, 1960, p.105; RODRIGUES, Silvio. Direito Civil. v. I. São Paulo: Max Limonad, 1962, p.92; DANTAS, San Thiago. Programa de direito civil. Rio de Janeiro: Editora Rio, 1979, p. 212.

${ }^{43}$ Dentre os autores contemporâneos, VENOSA, Silvio de Salvo. Direito civil: parte geral. São Paulo: 
pouco diferem entre si, mas que muitas vezes procuram se filiar à chamada teoria da realidade técnica ${ }^{44}$ que-a despeito de não negar a existência de realidades próprias aos agrupamentos humanos - entende que a personificação é puro efeito da técnica do direito.

\section{$2.4 \mathrm{O}$ posicionamento original de $\mathrm{J}$. Lamartine Corrêa de Oliveira}

Após minudenciar e realinhar segundo critérios inovadores uma vasta doutrina, J. Lamartine Corrêa de Oliveira propõe uma solução original para o problema da conceituação da pessoa jurídica. Por meio da concepção ontológico-institucionalista, Lamartine reconhece o substrato ôntico conformado(pelomenosnocasodasassociações) pela coletividade de homens que integram, em unidade, uma existência autônoma. Trata-se de uma "realidade permanente, individual, completa, incomunicável fonte de atividade consciente e livre, realidade distinta" ${ }^{95}$.

Atlas, 2003, p.259; GONÇALVES, Carlos Roberto. Direito civil brasileiro: parte geral. v. I. São Paulo: Saraiva, 2003, p.186; LISBOA, Roberto Senise. Manual de direito civil. 3.ed. São Paulo: Revista dos Tribunais, 2003, p.333.

${ }^{44}$ A teoria da realidade técnica que, como visto em notas anteriores, recebeu destacado acolhimento no Brasil, tem suas origens na doutrina francesa. Dentre outros autores, pode-se citar o pensamento de François Geny: "les concepts de sujet de droit, de droit subjectif, de personnalité morale, n'ont de valeur qu'en tant que moyens artificiels de l'élaboration juridique et que, cantonnés dans ce demaine, ils peuvent rendre de véritables services". Mais a frente, este autor, tratando da pessoa jurídica enuncia: "son élaboration laisse la voie ouverte au progrès, qui s'est déjà si largement réalisé dans la théorie des personnes morales". (GENY, François. Science et technique en droit privé positif. v. III. Paris: Sirey, 1921, p. 219 e 227 respectivamente).

${ }^{45}$ CORRÊA DE OLIVEIRA, A dupla crise da pessoa jurídica, p. 17.
A sensível diferença entre a pessoa humana e a pessoa jurídica estaria na substância. Segundo os postulados da filosofia tomista adotados pelo autor, os seres existentes poderiam ser diferenciados entre aqueles dotados de forma substancial e outros dotados de forma acidental.

Os seres de forma substancial seriam aqueles que não necessitariam de fundamentos extrínsecos para sustentar-se, ou seja, existiriam por si mesmos. Por outro lado, os seres de forma acidental não teriam existência em si mesmos, na medida em que seriam dependentes de outros seres de substância. ${ }^{46}$ Por conclusão, "o ser humano é reconhecido como indivíduo, mas não apenas indivíduo: substância também, isto é, ser que existe por si mesmo; e de natureza racional" ${ }^{47}$. Irredutível fim em si mesmo, a pessoa humana é dotada de dignidade. ${ }^{48}$ Mais que uma realidade ontológica, tratase de uma realidade axiológica, vez que "ser e valer estão intimamente ligados, em síntese indissolúvel, eis que o valor está, no caso, inserido no ser. $\mathrm{O}$ homem vale, tem a

${ }^{46}$ Explica J. Lamartine Corrêa de Oliveira que "quando falamos em substância e acidente, referimonos à ordem do ser enquanto existente. Enquanto que substância é o ser que existe por si mesmo, o acidente, que também é um ser, um ens, mas é um ens entis, um ser que existe como complemento ou acabamento de outro ser" (CORRÊA DE OLIVEIRA, Conceito de pessoa jurídica, p. 162).

${ }^{47}$ CORRÊA DE OLIVEIRA, José Lamartine; MUNIZ, Francisco José Ferreira. O Estado de Direito e os direitos da personalidade. Revista dos tribunais. a.69, v.532, fev. de 1980, p.17.

${ }^{48}$ Sobre os reflexos da expressão ética da pessoa na teoria da relação jurídica, cf. CARVALHO, Orlando de. A teoria geral da relação jurídica: seu sentido e limites. 2.ed. Coimbra: Centelha, 1981, p. 48. 
excepcional e primacial dignidade de que estamos a falar, porque ế $e^{\text {49 }}$.

A pessoa jurídica é um ser, uma unidade ontológica. Essa unidade, no entanto, não teria "forma substancial", mas sim "forma acidental". A pessoa jurídica, por sua vez, "como a pessoa humana, ela é um ser. E, mais, como a pessoa humana, ela é indivisa, individual. É permanente (...) Possui independência externa"50. Diversamente da pessoa natural, todavia, a pessoa jurídica "não é substancial. Depende, para existir, dos seres humanos, que estão sob sua existência. Entretanto, é ser, pois o acidente é ser" ${ }^{\text {51. }}$.

Não há que se falar em dignidade da pessoa jurídica ${ }^{52}$. Ainda que se aplique a ela a proteção dos direitos de personalidade, esta assertiva é limitada no que couber, conforme a ressalva que hoje se encontra no art. 52 do Código Civil de 2002, que reconhece uma diferença essencial entre a pessoa natural e a pessoa jurídica: esta última não é um fim em si mesmo e não pode ser considerada pessoa em sentido ético. Reside, aí, uma diferença essencial entre a pessoa natural e a pessoa jurídica. Nas palavras do nosso autor: "não se pode falar em uma dignidade ('Würde') da pessoa jurídica, ao contrário do que sucede com o Homem. Exatamente por não ser ela pessoa em sentido ético" ${ }^{53}$.

${ }^{49}$ Grifos no original, CORRÊA DE OLIVEIRA; MUNIZ, O Estado de Direito e os direitos da personalidade, p.16.

${ }^{50}$ Grifos nossos, CORRÊA DE OLIVEIRA, Conceito de pessoa jurídica, p. 164.

${ }^{51}$ Grifos nossos, CORRÊA DE OLIVEIRA, Conceito de pessoa jurídica, p. 164.

${ }^{52}$ CORRÊA DE OLIVEIRA, A dupla crise da pessoa jurídica. p. 20 e 135.

${ }^{53}$ CORRÊA DE OLIVEIRA, A dupla crise da pessoa jurídica, p. 20 e p.135.
O qualificativo "pessoa" seria inexo às pessoas jurídicas mediante um raciocínio, próprio à filosofia tomista, de analogia por atribuição. Assim, conclui J. Lamartine Corrêa de Oliveira conceituando a pessoa jurídica como "realidade análoga à pessoa humana, porque idêntica em inúmeros aspectos e distinta no mais importante: a substancialidade, que esta possui e aquela não. É pessoa, portanto. Mas não no sentido pleno da palavra e sim por analogia" ${ }^{54}$. Justamente pelo caráter analógico de atribuição destacado é que o realismo, neste autor, não se confunde com um criticável desvio antropomorfista, denunciado por Ferrara. ${ }^{55}$

Não bastaria afirmar a realidade da pessoa jurídica. Mostrava-se necessário conformar essa realidade à noção de direito subjetivo. Como entidades dotadas de personalidade, potencialmente, poderiam ser titulares de direitos subjetivos - não pelo poder de vontade ou pelo interesse juridicamente protegido, mas por uma ligação da ordem do ter, um lien d'appartenence, conforme expressou Jean Dabin, que firmaria a titularidade dum direito subjetivo deferido pelo direito em sentido objetivo. ${ }^{56}$

Em defesa de suas posições filosóficas, escreveu Lamartine que essa vinculação entre o direito objetivo e o direito subjetivo não

${ }^{54}$ CORRÊA DE OLIVEIRA, Conceito de pessoa jurídica, p. 165.

${ }^{55}$ FERRARA, Teoria delle persone giuridiche, p. 141.

${ }^{56}$ DABIN, J. Apud. CORRÊA DE OLIVEIRA, J. Lamartine. Conceito de pessoa jurídica. Tese apresentada à Faculdade de Direito da Universidade Federal do Paraná para concurso de livre docência de Direito Civil. Curitiba, 1962 (mimeo). 
significa uma opção legalista ou positivista, ${ }^{57}$ vez que o direito objetivo "abrange tanto o Direito Positivo quanto o Direito Natural. Assim, o papel do Direito Positivo é o de criar direitos subjetivos (os que não resultam do Direito Natural) ou meramente consagrar os emanados dessa ordem normativa mais alta e básica" ${ }^{58}$.

A concepção ontológico-institucionalista de pessoa jurídica defendida por Lamartine ${ }^{59}$ encontra seus fundamentos na chamada escola institucionalista francesa, ${ }^{60}$ inaugurada por Maurice Hauriou. Para compreender tal concepção, devem ser enfrentados dois dados que lhe estão pressupostos: as razões que justificam a proximidade teórica entre Lamartine e a escola institucionalista francesa, e os postulados institucionalistas por ele acolhidos para a conceituação da pessoa jurídica.

Sob um enfoque metodológico, a escola institucionalista francesa destaca-se por

${ }^{57}$ Noutra obra, escrita em co-autoria com Francisco José Ferreira Muniz, a mesma preocupação é expressa. Cf. CORRÊA DE OLIVEIRA, J. Lamartine; MUNIZ, Francisco José Ferreira. Curso de direito de família. 2.ed. Curitiba: Juruá, 1998, p. 25.

${ }^{58}$ CORRÊA DE OLIVEIRA, Conceito de pessoa jurídica, p.27.

59 "Nossa posição básica aproximou-se grandemente das teses dos autores institucionalistas" (CORRÊA DE OLIVEIRA, A dupla crise da pessoa jurídica, p. 11).

${ }^{60} \mathrm{Na}$ Itália, outra importante escola institucionalista, fundada por Santi Romano, desenvolvia uma concepção institucionalista absolutamente diversa da escola francesa. Tal fato pode ser percebido pela seguinte assertiva de Santi Romano “(...) noi non crediamo che l'istituzione sia fonte del diritto, e che quindi questo sia un effetto, un prodotto della prima, ma crediamo che fra il concetto di istituzione e quello di ordinamento giuridico, unitariamente e complessivamente considerato, ci sia perfetta identità." (ROMANO, Santi. L'ordinamento giuridico. Firenze: Sansoni, 1951, p. 33-34). rejeitar construções conceitualistas, mediante adoção de uma epistemologia indutiva ${ }^{61}$, fundada na observação dos fenômenos sociais como base de suas conclusões ${ }^{62}$. Para os autores dessa escola, a relação entre o Direito e os dados concretos da vida em sociedade tem de ser muito íntima.

A mesma perspectiva metódica é uma constante no pensamento de J. Lamartine Correa de Oliveira, que sempre ressaltou sua crítica quanto à "falta de maiores estudos de sociologia jurídica (...) falta de pesquisas sociológicas aplicadas a estudos de natureza pré-normativa", o que, inclusive, propiciaria uma manutenção do "Direito dos nossos países latino-americanos como mero reflexo do que em terras da Europa se escreve e se produz". ${ }^{63}$

A escola institucionalista francesa procurou desenvolver uma via alternativa entre o individualismo subjetivista, retratado pelos pensadores filiados ao liberalismo do Code de Napoleão, e o individualismo objetivista, exposto pelas correntes teóricas que buscavam reduzir o fenômeno jurídico ao direito objetivo. Justamente por isso, uma

${ }^{61}$ ENPC LATTS, Gilles Jeannot. Les associations, L'Etat et la théorie de l'institution de Maurice Hauriou. Les annales de la recherche urbaine. n. ${ }^{o} 89$, jun./2001, p. 19.

${ }^{62}$ Segundo Mirian Theresa Rooney, para os institucionalistas franceses "the emphasis is upon observation. (...) The empirical method of science and technology, wich directs many other twentieth century activities, influences the trend of their though.t" (ROONEY, Miriam Theresa. Introduction. In: BRODERICK, Albert. The french institutionalists: Maurice Hauriou, Georges Renard, Joseph T. Delos. trad. Mary Wlling. Massachusetts: Harvard University Press, 1970, p. 1).

${ }^{63}$ CORRÊA DE OLIVEIRA, A dupla crise da pessoa jurídica, p.93. 
das linhas doutrinárias do institucionalismo francês busca pôr em evidência "a existência de atividades jurídicas irredutíveis às manifestações do direito individual, ao contrato e ao direito do Estado". ${ }^{64}$

J. Lamartine Correa de Oliveira posicionou-se decididamente como severo crítico do normativismo jurídico, ${ }^{65}$ a ser debelado por um ensino jurídico crítico e democrático. ${ }^{66}$ Amparava-se, ademais, numa filosofia do direito que - ao propugnar pela precedência de valores transpositivos sobre as normas e os ordenamentos jurídicos estava imunizada às ilusões racionalistas e materialmente orientada a uma perspectiva de inserção do homem em seu contexto histórico e social. ${ }^{67}$

Aliás, outro dado marcante da escola institucionalista francesa é a profunda ligação com as teorias jusnaturalistas e com a Doutrina Social da Igreja e da filosofia

${ }^{64}$ DELOS, J,-T. La théorie de l'Institution. La solution réaliste du problème de la personnalitè morale et le droit à fondement objectif. Archives de philosophie du droit et de sociologie juridique. n. ${ }^{\circ}$ 1-2, Cahier double, Recueil Sirey, 1931, p. 99.

${ }^{65} \mathrm{O}$ autor, em tom poético, menciona uma "lufada de ar fresco realista em meio aos abafados formalismos tecnicistas e positivistas!". (CORRÊA DE OLIVEIRA, A dupla crise da pessoa jurídica, p.475).

${ }^{66}$ Pôde-se colher a opinião do autor nos escritos CORRÊA DE OLIVEIRA, J. Lamartine. A função social do advogado e a crise do ensino jurídico. In: semana do advogado (7 a 11 de agosto de 1972). Ordem dos advogados do Brasil - Seção do Paraná, 1972; CORRÊA DE OLIVEIRA, J. Lamartine; MUNIZ, Francisco José Ferreira; APPEL, Emmanuel José. Cultura, ensino e universidade: contribuição da UFPR ao debate constitucional. Curitiba: UFPR, 1986.

${ }^{67}$ CORRÊA DE OLIVEIRA; MUNIZ, O Estado de Direito e os direitos da personalidade, p. 17. aristotélico-tomista $^{68}$. Nem tanto em Hauriou, mas, sobretudo, no pensamento de Renard e Delos, as premissas jusnaturalistas ${ }^{69}$ e a proximidade com a Doutrina Social da Igreja são manifestas. ${ }^{70}$

Domesmomodo, em diversasoportunidades, Lamartine declarou que seu pensamento era filiado ao jusnaturalismo ${ }^{71}$, tendo sublinhado a importância da Doutrina Social da Igreja, seja na busca de uma solução intermediária entre os excessos do liberalismo e do socialismo, seja no reconhecimento da importância dos grupos intermediários entre o indivíduo e o Estado. Ao final de sua tese sobre o conceito de pessoa jurídica, este autor expressivamente cita a encíclica Mater et Magistra de João XXIII para justificar a importância de uma concepção realista das instituições mediárias entre indivíduo e Estado ${ }^{72}$. Por todas essas razões, J. Lamartine Corrêa de Oliveira encontrou na escola institucionalista

${ }^{68}$ CORREA DE OLIVEIRA, J. Lamartine. A justiça social e o direito privado brasileiro (denúncia de uma 'opção pelos ricos': tese n.19). In: Conferência nacional da ordem dos advogados do Brasil. Rio de Janeiro: Folha Carioca Editora LTDA., 1982.

${ }^{69}$ ROONEY, Miriam Theresa. Introduction. In: BRODERICK, Albert. The french institutionalists: Maurice Hauriou, Georges Renard, Joseph T. Delos. trad. Mary Wlling. Massachusetts: Harvard University Press, 1970, p. 3)

${ }^{70}$ GRESSAYE, Jean Brèthe de la. The sociological theory of the institution and french juristic thought. In: BRODERICK, Albert. The french institutionalists: Maurice Hauriou, Georges Renard, Joseph T. Delos. trad. Mary Wlling. Massachusetts: Harvard University Press, 1970, p. 22).

${ }^{71}$ Nesse sentido, conferir citações do pensamento de J. Lamartine Corrêa de Oliveira na nota n. 10 desta monografia.

${ }^{72}$ CORRÊA DE OLIVEIRA, Conceito de pessoa jurídica, p.171. 
francesa fortes subsídios para construir sua concepção ontológico-institucionalista de pessoa jurídica.

Do criador dessa escola, Maurice Hauriou, Corrêa de Oliveira colheu suas últimas conclusões, que identificavam a instituição como uma realidade entre o indivíduo e o Estado, que atua mediante a organização de um grupo vinculado por manifestações comunitárias. ${ }^{73} \mathrm{O}$ autor aplaude, ainda, a diferenciação entre personalidade moral, como algo que surge na realidade social, e personalidade jurídica como um simples aperfeiçoamento dessa realidade que nada cria, nada transforma. ${ }^{74}$

Pode-se dizer que a noção de pessoa jurídica em Maurice Hauriou encontra certa correspondência com a teoria realista, exposta anteriormente. Trata-se, entretanto, de um realismo que rejeita o voluntarismo ${ }^{75}$. $\mathrm{J}$. Lamartine Corrêa de Oliveira, embora reconheça a importância do pensamento de Maurice Hauriou, tece críticas severas ao idealismo platônico desse autor, que identificava na idéia de atuação (l'idée d'ouvre) o elemento básico

\footnotetext{
${ }^{73}$ Para Hauriou: "una istituzione è una idea di opera o di intrapresa, che si realizza e dura giuridicamente in un ambiente sociale; per la realizzazione di tale idea, si organizza un potere che la fornisce di organi; d'altra parte, tra i membri del grupo sociale che è interessato alla realizzazione dell'idea si attuano manifestazioni comunitarie, dirette dagli organi del potere regolate da procedure". (HAURIOU, Maurice. Teoria dell'istituzione e della fondazione. Milano: Giuffrè, 1967, p.12). Sobre as linhas mestras desse autor, cf. GURVITCH, G. Les idées maitresses de Maurice Hauriou. Archives de philosophie du droit et de sociologie juridique. n. 1-2, Cahier double, Recueil Sirey, 1931.

${ }^{74}$ Com ressalvas para a terminologia equívoca 'personalidade moral', a importância dessa diferenciação é destacada para explicar a dupla crise, cf. CORRÊA DE OLIVEIRA, A dupla crise da pessoa jurídica, p.475.

75 VELGE, Henri. Associations et fondations en Belgique. Bruxelles: Bruylant, 1942, p. 86.
}

para se formar uma instituição. ${ }^{76}$ Simpatia muito maior nota-se entre Lamartine e os prosseguidores de Maurice Hauriou, os autores franceses Georges Renard, J.-T Delos, e o belga, René Clémens.

Segundo Renard, assim como na natureza haveria uma gradação entre os organismos vivos (desde os mais simples até o mais complexo de todos eles, o ser humano), nas inúmeras instituições surgidas em sociedade, poder-se-ia perceber uma diferenciação entre elas pelo grau ontológico. ${ }^{77}$

$\mathrm{Na}$ sociedade, integrada por seres vivos e por instituições, apenas o homem seria titular de todas as características ontológicas que justificariam a atribuição de personalidade. Nessa perspectiva, algumas instituições alcançariam um nível tão elevado de organização e expressão real em sociedade que passariam a ter uma existência diferenciada em face de todas as demais pessoas, ou seja, "existiriam erga omnes como as pessoas humanas"78.

Essas entidades, embora destituídas de um substrato idêntico ao ser humano, seriam consideradas pessoas mediante a "analogia de atribuição", por meio da qual J. Lamartine Corrêa de Oliveira propõe o reconhecimento de personalidade real às pessoas jurídicas. E esta opção teórica é construída a partir de Renard $^{79}$. Ademais, é na obra desse pensador que Lamartine encontra suporte para sustentar

${ }^{76}$ CORRÊA DE OLIVEIRA, Conceito de pessoa jurídica, p.132.

${ }^{77}$ RENARD, Georges. Les degrés de l'existence institutionnelle. In: La théorie de l'institution: essai d'ontologie juridique. Paris: Sirey, 1930, p. 225.

${ }^{78}$ RENARD, Les degrés de l'existence institutionnelle, p. 243.

${ }^{79} \mathrm{RENARD}$, Les degrés de l'existence institutionnelle. p. 268. 
sua concepção ontológica da pessoa jurídica, vez que é "a potência de ser (potência no sentido filosófico, de virtualidade) que diferencia a instituição pessoa moral daquela que não o é" ${ }^{\circ 0}$.

Tal como René Clémens alerta, “o legislador não define o real. Ele observa as atividades e as relações. Ele as regulamenta" "1, isto é, atua normativamente quase na periferia da entidade pré-regulada. Justamente por isso, J. Delos assevera que "a teoria da personalidade moral é somente uma interpretação, uma transcrição metafísica de certos dados sociológicos" $"$.

J. Lamartine Corrêa de Oliveira conclui, assim, que as pessoas jurídicas, "no plano ontológico, são verdadeiras pessoas, são verdadeiros sujeitos de direito, embora sua personalidade não seja idêntica mas meramente analógica à do ser humano. Num plano distinto, lógica e cronológicamente posterior, o Estado reconhece, declara realidade que preexiste tal declaração (...)" ${ }^{\text {»3 }}$.

Não se trata, portanto, de desprezar o papel do Direito na teoria da pessoa jurídica. Trata-se de negar caráter constitutivo ao reconhecimento dessa personalidade, vez que, quando o direito objetivo reconhece um agrupamento real como pessoa jurídica,

${ }^{80}$ CORRÊA DE OLIVEIRA, Conceito de pessoa jurídica, p. 140

${ }^{81}$ CLÉMENS, René. Personnalité morale et personnalité juridique. Paris: Sirey, 1935, p.168.

${ }^{82}$ DELOS, J,-T. La théorie de l'Institution. La solution réaliste du problème de la personnalitè morale et le droit à fondement objectif. Archives de philosophie du droit et de sociologie juridique. n. ${ }^{\circ}$ 1-2, Cahier double, Recueil Sirey, 1931, p. 99.

${ }^{83}$ CORRÊA DE OLIVEIRA, Personalidade jurídica da sociedade irregular, p. 155-156. reconhece algo que já existe. Essa operação é importante, mas não vai além de uma mera declaração do que preexiste ${ }^{84}$.

\section{DO CONCEITO DE PESSOA JURÍDICA À DUPLA CRISE DA PERSONALITAS IURIS}

A partir de suas profundas reflexões sobre o conceito da pessoa jurídica, J. Lamartine Corrêa de Olivera, na Dupla crise da pessoa jurídica (1979), promove uma viragem crítica: do descompasso entre a realidade ontológica dos agrupamentos sociais e o tratamento jurídico por eles recebido, seria perceptível uma dupla crise, pertinente ao reconhecimento e à função dessas entidades.

A compreensão dessa tese parte de alguns pressupostos. O primeiro reside na concepção ontológico-institucionalista de pessoa jurídica, cuja personalidade seria reconhecida por analogia ao ser humano, conforme exposto anteriormente. J. Lamartine Corrêa de Oliveira defende intensamente tal concepção, que pressupõe a existência de uma essência destas entidades, rechaçando qualquer visão filosófica nominalista.

A partir dessa concepção essencialista, na tese sobre a dupla crise da pessoa jurídica, Lamartine empreende um profundo estudo de

${ }^{84}$ Nesse sentido, impressionam as construções teóricas dos autores suíços cujas reflexões foram feitas com base num Código que, flagrantemente, adotou orientações realista. Citem-se TUOR, Pierre. Le code civil suisse. 2.ed française d'apres la 5a édition allemande par Henri Deschenaux. Zurich: Éditions Polygraphiques, 1950, p.99 e ROSSEL, Virgille; MENTHA, F.-H. Manuel du droit civil suisse. Lausanne/Genève: Payot, 199-, p. 122-123. 
direito comparado, investigando os diferentes regramentos que os diversos sistemas jurídicos adotam perante essa realidade material-espiritual das instituições sociais. Após refletir sobre os ordenamentos jurídicos alemão, italiano, francês, português, belga, suíço, espanhol e argentino, propõe uma classificação que os diferencia segundo sejam minimalistas ou maximalistas.

Os ordenamentos jurídicos minimalistas seriam aqueles nos quais bastaria um mínimo de correspondência analógica entre os agrupamentos sociais e o ser humano para se admitir a personificação (como, v.g, no direito francês). Os ordenamentos jurídicos maximalistas, por sua vez, seriam aqueles nos quais se exigiria um máximo de analogia entre essas entidades e o ser humano para que se pudesse reconhecer a personalidade jurídica (como, v.g, no direito suíço) ${ }^{85}$

Em razão dos modelos minimalistas ou maximalistas, esses mesmos ordenamentos jurídicos poderiam adotar posições monistas, quando a pessoa jurídica é a única forma de autonomização perante as esferas jurídicas individuais, e posições dualistas, quando, ao lado da pessoa jurídica, outras figuras permitem esta autonomia (daí a dualidade, como, v.g., no direito alemão, entre a pessoa jurídica e a Gesamthandgemeinschaft).

A partir daí, confrontando a essência ontológico-institucionalista dos agrupamentos sociais e os diferentes modelos adotados pelos ordenamentos jurídicos, para Lamartine, seria possível verificar a existência de uma dupla crise.

A primeira crise seria de estrutura, exteriorizada nas deficiências dos sistemas

${ }^{85}$ CORRÊA DE OLIVEIRA, A dupla crise da pessoa jurídica, p. 475, 77 e 83. de reconhecimento das entidades sociais como pessoas de direito. Nos sistemas maximalistas, essa crise ficaria exposta nas situações em que essas entidades - embora sem alcançar os requisitos suficientes para (analogamente) ser reconhecidas como pessoas - concretamente se autonomizam de seus membros, sendo-lhes reconhecida a titularidade de direitos subjetivos. $\mathrm{O}$ direito alemão, como sistema maximalista e dualista, refletiria essa crise. ${ }^{86}$

Nos sistemas minimalistas, a crise implicaria uma dialética própria. A mínima analogia com o ser humano bastaria para a personificação, o que conduziria a um conseqüente e descomensurado aumento das entidades personalizadas. Para pôr limites à criação dessas entidades, por sua vez, haveria um recrudescimento da concepção de que a personalidade é atribuída pela lei, o que resultaria na negação desse reconhecimento a uma série de agrupamentos reais que, contraditoriamente, vez ou outra, seriam titulares de direitos subjetivos. Este seria o caso do sistema francês, identificado pelo autor como minimalista e monista. ${ }^{87}$

Mas por qual razão isso induziria a uma sintomática de crise? Para compreender essa construção, deve-se sublinhar que, para Corrêa de Oliveira, capacidade e personalidade são figuras absolutamente distintas. A personalidade seria uma qualidade una, invariável e insuscetível de gradações ou limitações, correspondente à potencial titularidade de direitos e obrigações. Só quem é pessoa pode ser titular de direitos ou

${ }^{86}$ CORRÊA DE OLIVEIRA, A dupla crise da pessoa jurídica, p. 169.

87 “CORRÊA DE OLIVEIRA, A dupla crise da pessoa jurídica, p. 170. 
vincular-se a obrigações; por conseqüência, todo aquele que é titular de direitos ou se vincula às obrigações deve ser considerado pessoa. ${ }^{88}$

Apenas a capacidade jurídica (da qual a personalidade seria indispensável pressuposto) admitiria gradações ou limitações para a aquisição ou o exercício deste ou daquele específico direito subjetivo (como, por exemplo, a limitação da titularidade de determinados direitos subjetivos para os estrangeiros $)^{89}$. Desse modo, na medida em que esses ordenamentos conferem direitos a entidades que, por insuficiência de compleição, não são consideradas pessoas, surgiria uma insuperável contradição como sintoma de uma crise estrutural do sistema quanto ao reconhecimento dessas entidades.

A segunda crise, por sua vez, seria uma crise de função. A importância e o poder das entidades personificadas não permitiriam uma redução da apreensão do fenômeno

\footnotetext{
${ }^{88}$ A mesma concepção de personalidade é encontrada em CARVALHO, Orlando de. Teoria geral do direito civil. Sumários desenvolvidos para uso dos alunos do 2. ${ }^{\circ}$ ano. Coimbra: Centelha, 1981, p. 164.

${ }^{89}$ A diferenciação entre personalidade e capacidade iluminou suas críticas à parte geral do então Projeto de Código Civil brasileiro (hoje, Lei n. ${ }^{\circ} 10.406 / 2002$ ), bem como seus elogios à parte geral do código civil português de 1966. Sobre o assunto, cf. CORRÊA DE OLIVEIRA, J. Lamartine. A parte geral do anteprojeto de Código Civil. Revista dos Tribunais, a.63, v.466, ago. de 1974, p.270 e CORRÊA DE OLIVEIRA, J. Lamartine. Notícias sobre a parte geral do novo código civil português. Revista da Faculdade de Direito da UFPR. Curitiba, a.12, n. 12, 1969, p. 64. Destaque-se a percepção da diferença entre capacidade de direito e personalidade no pensamento de Teixeira de Freitas (CORRÊA DE OLIVEIRA, J. Lamartine. A teoria das pessoas no esboço de Teixeira de Freitas. Superação e permanência. In: SCHIPANI, Sandro. Augusto Teixeira de Freitas e il diritto latinoamericano. Padova: Cedam, 1988, p.364).
}

jurídico aos seus dados estruturais, o que é muito próprio à chamada jurisprudência dos conceitos. Os imperativos de justiça e os valores inerentes aos diversos ordenamentos jurídicos, paulatinamente, por força, em especial, de uma construção pretoriana, passaram a redimensionar o fenômeno jurídico da personificação mediante limites de função, encontrando guarida em outras metodologias, como a chamada jurisprudência dos interesses e, sobretudo, na chamada jurisprudência dos valores $^{90}$.

\subsection{A crise de reconhecimento das pessoas jurídicas}

No direito brasileiro a crise de reconhecimento das pessoas jurídicas apresenta contornos próprios à orientação minimalista e monista de nosso ordenamento, cuja categorização é justificável pelas seguintes razões.

Ante um mínimo de analogia entre os agrupamentos sociais e a pessoa humana, já se possibilita a personificação jurídica, daí o minimalismo. Isto é verificável, e.g., pela personificação das sociedades simples no direito brasileiro, não se exigindo nem mesmo uma estrita separação patrimonial em relação aos sócios (art.997, VII do Código Civil de 2002).

Omonismo, porsuavez, éretratadomediante o sistema das disposições normativas - segundo o qual, para a personificação, é necessário que

\footnotetext{
${ }^{90}$ Sobre o assunto, cf.HECK, Philip. Interpretação da lei e jurisprudência dos interesses. trad. José Osório. São Paulo: Saraiva, 1948; LARENZ, Karl. Metodologia da ciência do direito. Lisboa: Calouste Gulbekian, 1997; POMBO, Eugenio Llamas. Orientaciones sobre el concepto y el método del derecho civil. Buenos Aires: Rubinzal Culzoni, 2002.
} 
a entidade detenha características estruturais e funcionais minimamente correspondentes ao modelo legal. ${ }^{91}$ Em virtude do monismo, só se consideram pessoas jurídicas de direito privado aquelas entidades tipificadas pelo legislador (art. 44 do Código Civil em vigor). Apenas a elas é possível a inscrição dos atos constitutivos no registro.

Diante disso, para uma pluralidade de agrupamentos sociais, por mais que detenham características reais que justificariam a personificação, resta um limbo jurídico. Conforme anota um manualista contemporâneo, sem propor qualquer solução teórica, "nem todo grupo social constituído para a consecução de fim comum é dotado de personalidade. Alguns, malgrado possuam características peculiares à pessoa jurídica, carecem de requisitos imprescindíveis à personificação" 92 . Chega-se mesmo a defender a existência de "grupos com personificação anômala"93.

À sua época, J. Lamartine Corrêa de Oliveira procurou enfrentar esse problema investigando as figuras da massa falida, do espólio, da herança jacente e vacante, do

${ }^{91}$ J. Lamartine Corrêa de Oliveira explica o sistema das disposições normativas como o que "estabelece limites que então catalogamos basicamente em duas categorias. O primeiro limite é o de ordem ontológica e estrutural e diz respeito ao fato de que o estado só pode reconhecer como pessoas jurídicas as que se submetem a determinados requisitos formais que a lei estabelece. Os requisitos formais constituem um instrumento de que a lei se utiliza para fazer com que o reconhecimento só se refira àquelas realidades institucionais que, ontológica estruturalmente, sejam pessoas jurídicas" (CORRÊADE OLIVEIRA, A dupla crise da pessoa jurídica, p. 22).

${ }^{2}$ GONÇALVES, Direito civil brasileiro: parte geral, p.192.

${ }^{93}$ VENOSA, Silvio de Salvo. Direito Civil: parte geral, p.265. condomínio por unidades autônomas e das sociedades irregulares. Para tanto, teve um importante estímulo com a entrada em vigor do Código de Processo Civil de 1973 (Lei n. ${ }^{\text {o }}$ 5.869/73).

Isso porque, atendendo a necessidades da prática judiciária, aquele Código atribuiu capacidade para ser parte a todas as entidades discriminadas em seu art. 12, provocando a seguinte questão: se essas entidades podem ser parte, não seriam elas autênticas pessoas? Sendo titulares de ação em sentido processual e, portanto, de direitos subjetivos, não seriam pessoas jurídicas?

A indagação prossegue. A cada vez que $\mathrm{o}$ art. 12 indica operações de representação como, e.g., da massa falida que é "representada" pelo síndico, da sociedade sem personalidade, que é representada pela pessoa a quem couber a administração dos seus bens, implicitamente não estaria reconhecendo personalidade a essas entidades? Conforme observação de Pontes de Miranda, "não há representação sem haver pessoa que se represente e pessoa que represente". ${ }^{94} \mathrm{Se}$ a personalidade é, em síntese, qualidade una, invariável e insuscetível de gradações, correspondente à potencial titularidade de direitos e obrigações, todas essas entidades deveriam ser consideradas pessoas.

A solução satisfatória do problema não adviria das propostas normativistas. Tampouco seria aceitável uma cisão entre o direito material e o direito processual, reconhecendo-se a uma entidade que não "é" - um ser inexistente para o direito - a

${ }^{94}$ PONTES DE MIRANDA, Francisco Cavalcanti. Comentários ao Código de Processo Civil. Rio de Janeiro: Forense, 1973, p.249. 
capacidade processual. Segundo J. Lamartine Corrêa de Oliveira, "entendemos que, nos casos de aparente contradição, ou a 'parte' não é verdadeiramente a 'entidade' que um hábito de linguagem como tal designa ou ela o é, mas em tal caso a entidade é parte e é sujeito de direitos e, portanto, pessoa". ${ }^{95}$

A potencial titularidade de direitos, por outro lado, não é suficiente para definir o ser pessoa. Trata-se de um efeito decorrente dessa condição existencial, que não circunscreveria a sua essência. Não se pode fugir de uma análise ontológica dessas entidades, vez que "em todos os sistemas, é necessário guardar fidelidade ao ser, respeitar os limites do ontológico". ${ }^{96}$

Seguindo esse caminho, o autor nega personalidade à massa falida por não discernir nela uma autêntica pessoa, mas mero patrimônio que passa a ser administrado por sujeito diverso do devedor. A expressão representação, lançada no art. 12, caput, do Código de Processo Civil, teria sido utilizada em sentido não técnico. O síndico, em verdade, exerceria um munus e, em razão dele, seria a verdadeira parte de ofício ${ }^{97}$.

${ }^{95}$ CORRÊA DE OLIVEIRA, A dupla crise $d a$ pessoa jurídica, p. 203.

${ }^{96}$ CORRÊA DE OLIVEIRA, A dupla crise da pessoa jurídica, p. 607.

${ }^{97}$ Segundo J. Lamartine Corrêa de Oliveira "a noção de parte de ofício (Partei kraft Amts), como explicação para o caso do síndico da massa falida, é aceita pela jurisprudência do Reichsgericht e por boa parte da doutrina alemã e abrange, além do caso do síndico da massa falida, o caso do inventariante e do testamenteiro, dentre outros (...) Exatamente porque sua qualidade de parte decorre de munus que lhe foi conferido (ou seja, é parte por ser administrador da massa, e nessa qualidade) é que se explicam as aparentes contradições apontadas por Rosenberg (...) Assim, só por uma figura de linguagem pode ser dito que a massa é aparte. A massa não é parte
Qualificação semelhante caberia ao espólio eàherança, jacente ou vacante. Nenhuma dessas figuras guarda qualquer relação ontológica que lhes justifique o reconhecimento de personalidade. Trata-se de figuras muito mais afeitas aos objetos, visto que seus verdadeiros titulares são os herdeiros. Na hipótese de herança jacente, há mera indeterminabilidade do sujeito, ante a provisória incerteza quanto a sua titularidade ${ }^{98}$. Mais uma vez, Lamartine entende haver, nesses casos, parte de ofício. A expressão representação escrita no caput do art. 12 do CPC seria uma impropriedade terminológica ${ }^{99}$.

Ao tratar do condomínio por unidades autônomas e das sociedades irregulares, J. Lamartine Corrêa de Oliveira posicionase de maneira particularmente diversa. $\mathrm{O}$ autor percebe e aponta que o próprio direito material, mais precisamente o artigo $63, \S 3 .{ }^{\circ},{ }^{100}$ da Lei de Incorporações (Lei n. $\left.{ }^{\circ} 4.591 / 64\right)$, conferiria ao condomínio a titularidade de um direito de preferência na hipótese de leilão de unidade em construção, possibilitando, inclusive, a adjudicação de bens. Ora, se o condomínio pode ser titular do direito de propriedade, tem-se por conclusão necessária a sua personalidade jurídica.

porque a massa não é, não integra o mundo dos sujeitos de direito.(...) Parte, de ofício, é o síndico". (CORRÊA DE OLIVEIRA, A dupla crise da pessoa jurídica, p. 209-211).

${ }^{98}$ CORRÊA DE OLIVEIRA, A dupla crise da pessoa jurídica, p. 214.

99 PONTES DE MIRANDA, Comentários ao Código de Processo Civil, p.329.

100 " $33 .^{\circ}$ No prazo de 24 (vinte e quatro) horas após a realização do leilão final, o condomínio, por decisão unânime de assembléia geral em condições de igualdade com terceiros, terá preferência na aquisição dos bens, caso em que serão adjudicados ao condomínio". 
Após afastar a equivocada noção de que o condomínio seria titular de frações ideais do imóvel (tese que contrariava o expresso texto do $\S 2 .^{\circ}$ do art. $1 .^{\circ}$ da Lei n. $\left.{ }^{\circ} 4.591 / 64\right)$, J. Lamartine Corrêa de Oliveira identifica elementos que, sob o viés ontológico, justificam a qualificação do condomínio em edifício por andares como pessoa jurídica: "Não temos a menor dúvida em afirmar a personalidade jurídica do condomínio por unidades autônomas, uma vez que irrecusável sua aptidão à titularidade de direitos, deveres, obrigações, pretensões, no plano do direito material (...)". ${ }^{101}$

No que diz respeito às sociedades irregulares, Lamartine desenvolve raciocínio semelhante. Ante a expressa capacidade processual (art. 12, inc. VII, do CPC) atribuída a sociedades não registradas (irregulares), que ontologicamente já apresentam a mesma essência que se expõe ao mundo após o registro -, não haveria como negar sua personalidade ${ }^{102}$. Tal fato exige solução que extrapola a mera comunhão ou a figura da sociedade em comum (art. 986 do Código Civil). ${ }^{103}$

${ }^{101}$ CORRÊA DE OLIVEIRA, A dupla crise $d a$ pessoa jurídica, p. 227.

${ }^{102}$ Em ensaio monográfico específico sobre o tema, J. Lamartine Corrêa de Oliveira conclui que as sociedades irregulares "são pessoas jurídicas, pois que têm alguns direitos, e basta ter algum direito, ou só um direito, para ser pessoa. E elas têm vários direitos, reconhecidos pela ordem jurídico-positiva. E não é possível ser-se sujeito de direitos sem se ser pessoa, o que seria uma contradictio in terminis" (CORRÊA DE OLIVEIRA, J. Lamartine. Personalidade jurídica da sociedade irregular. Revista da Faculdade de Direito. Curitiba, a. 10, n. 10, 1964-1967, p. 161).

${ }^{103}$ Nesse sentido, a crítica do autor ao texto do Código Civil em vigor: "Não temos nenhuma dúvida: o Projeto de Código Civil equacionou de modo insatisfatório
Ajurisprudência brasileiraé freqüentemente instada a tratar das situações em que direitos subjetivos ou deveres jurídicos são imputados às sociedades irregulares. Por vezes, reconhece-se o problema teórico como uma contradição quase sem explicação. Cite-se, neste sentido, voto do Ministro Sálvio de Figueiredo Teixeira em recurso especial ${ }^{104}$ : "A capacidade para, pessoalmente ou por representante, exercer atos da vida civil, surge com a personalidade, somente quando passa a existir uma 'pessoa' (...) A rigor, portanto, somente as pessoas naturais ou jurídicas possuem qualidade para figurar como parte em processo judicial, porque as únicas capazes de direitos e obrigações na órbita civil. (...)". Em seguida, julga-se que "Os condomínios irregulares existentes no distrito Federal tem legitimidade ativa para ajuizar Ação de Cobrança das cotas para satisfazer as despesas comuns consoante proclama a jurisprudência desta Colenda Corte. (...)"

Saliente-se a exposição da questão teórica. É irrepreensível. Ao apresentar uma solução, todavia, lança-se mão do argumento de que, aqui, haveria uma situação excepcional que, a despeito disso, não subverteria a ordem jurídica: "O legislador de 1973, contudo, talvez com certo desprendimento a este rigor

o problema da sociedade em fase de constituição. Pretendeu romper com a reconhecidamente ruim (porque contrária à natureza e porque contém implícito reconhecimento de suposto efeito transformador do registro: transformador de sujeitos de direito sem se ser pessoa, o que seria uma contradictio in terminis" (CORRÊA DE OLIVEIRA, Personalidade jurídica da sociedade irregular, p. 161).

${ }^{104}$ STJ. Recurso Especial n. ${ }^{\circ} 14.180-0$ SP. 4. ${ }^{\text {a }}$ turma. Rel. Min. Sálvio de Figueiredo Teixeira. DJ. 28.06.1993. 
científico, imbuído, porém, de louvável senso prático, inovou (...) Serão representadas e juízo, ativa e passivamente: VII - as sociedades sem personalidade jurídica, pela pessoa a quem couber a administração de seus bens. (...)". Daí a conclusão pela perplexidade "Percebe-se, portanto, que a regra introduzida no estatuto processual de 1973 teve caráter eminentemente excepcional, colimando, ao que se constata, apenas tornar menos gravosa a situação processual dos que litigam com as chamadas sociedades de fato, sem, com isso, subverter a ordem jurídica (...)".

Subversão à ordem jurídica ou predominância da realidade em face do estrito texto da lei? Em data recente, um problema urbano muito próprio ao século XXI encontrou solução no Tribunal de Justiça do Distrito Federal - por meio da expressa adoção e citação do pensamento de J. Lamartine Corrêa de Oliveira-, prestigiandose a personalidade das sociedades irregulares, no decidir questão atinente a condomínio irregular. Consta no voto da desembargadora Carmelita Brasil que "Os condomínios irregulares existentes no distrito Federal têm legitimidade ativa para ajuizar Ação de Cobrança das cotas para satisfazer as despesas comuns consoante proclama a jurisprudência desta Colenda Corte. (...)".

A relatora fundamenta seu pensamento aduzindo que "Lamartine Corrêa de Oliveira, com muita propriedade, enfatiza o fato de as sociedades irregulares terem capacidade, tanto ativa como passiva, de estar em juízo. (...) Enquanto não desfeita a sociedade irregular subsistem e irradiam seus efeitos jurídicos, principalmente os decididos em assembléia". Retorna-se à questão: subversão à ordem jurídica ou predominância da realidade em face do estrito texto da Lei?
Isso depende de uma escolha material, onticamente definidora. Carmelita Brasil explicita a exata convicção que "as sociedades ou associações irregulares fazem parte da realidade deste País”, sendo assim: “(...) impossível é ignorar as repercussões de seus atos no mundo jurídico. E negar o pagamento de despesas condominiais, pelo simples fato de o condomínio ser irregular, é buscar o enriquecimento ilícito, que repugna o direito" ${ }^{105}$. Nas palavras de J. Lamartine Corrêa de Oliveira: "quanto a norma não mais qualifica adequadamente o ser que regula, o sistema entra em crise" ${ }^{\prime 106}$.

Para superar a crise de reconhecimento, J. Lamartine Corrêa de Oliveira e Arnold Wald propuseram nova redação ao texto do Projeto de Código Civil, correspondente ao art. 45 do Código em vigor, pautado pela diferenciação entre capacidade e personalidade, reiteradamente defendida na obra sobre a dupla crise da pessoa jurídica:

\footnotetext{
${ }^{105}$ TJDF. Embargos Infringentes na apelação cível n. ${ }^{\text {1 }}$ 1999.01.1.052850-9. 1. ${ }^{\text {a }}$ Câmara Cível. Relatora Desembargadora Carmelita Brasil, j. 13.12.2000. Em <http: www.tj.df.gov.br>, acesso em 1.05.05.

${ }^{106}$ CORRÊA DE OLIVEIRA, A dupla crise da pessoa jurídica, p.607. Ainda que com outras palavras, em sentido muito similar, cf. JOSSERAND, Louis. Cours de droit civil positif français. 3. ed. Paris: Sirey, 1938, p.383. Em recente tese de doutoramento, o Professor Marcos Bernardes de Mello propõe outra solução, mediante um alargamento da noção de sujeito de direito: "Para nós, diferentemente, capacidade jurídica constitui atributo dos sujeitos de direito, não apenas das pessoas. É, assim, conceito mais amplo que o de personalidade, uma vez que há mais sujeitos de direito do que pessoas. Toda pessoa, porque também é, necessariamente, sujeito de direito, tem capacidade jurídica; no entanto, também é sujeito de direito quem, mesmo sem ser pessoa, é titular de algum direito ou de uma situação jurídica qualquer" (BERNARDES DE MELLO, Marcos. Teoria do fato jurídico: plano da eficácia. São Paulo : Saraiva, 2003, p.118).
} 
"Art. 45. Começa a existência legal das pessoas jurídicas de Direito Privado com a conclusão dos atos de constituição, mas a capacidade plena de direito só é adquirida com a inscrição de tais atos no respectivo registro, precedida, quando necessário, de autorização ou aprovação"107.

\subsection{A crise de função e a desconsideração da personalidade jurídica}

O professor Luiz Edson Fachin - sucessor congenial de J. Lamartine Corrêa de Oliveira na titularidade da cadeira de direito civil da UFPR e igualmente alimentado pelo espírito crítico daquela escola - alerta que "nas sociedades de exploração, ao redor dos conceitos encastelados pelas hábeis mãos da lógica formal, se enfileiram fatos que denunciam o outono do conformismo racional" 108 .

A advertência serve como uma luva. Porque a segunda crise da pessoa jurídica correspondente à crise de função - inserta-se num fenômeno maior, isto é, no crepúsculo de uma metodologia conceitualista em direito privado, incapaz de suportar o "contraste entre a fidelidade à lógica formal do sistema e a fidelidade à justiça e às finalidades humanas e sociais do direito" 109 .

Longe de ser um produto de laboratório das academias jurídicas, a crise de função surgiu como um imperativo de justiça

${ }^{107}$ CORRÊA DE OLIVEIRA, J. Lamartine; WALD, Arnold. Emendas ao projeto de código civil. Rio de Janeiro: Ordem dos Advogados do Brasil, 1984, p.27.

${ }^{108}$ FACHIN, Luiz Edson. Teoria crítica do Direito Civil. Rio de Janeiro: Renovar, 2000, p.2.

${ }^{109}$ CORRÊA DE OLIVEIRA, A dupla crise da pessoa jurídica, p.605. proveniente dos inúmeros casos em que a personalidade jurídica era funcionalizada a objetivos desconformes ao ordenamento jurídico, como anteparo para operações abusivas, se não puramente ilícitas. ${ }^{110}$

Essas situações compeliram os juristas a tomar posição entre sustentar o dogma genérico de que "as pessoas jurídicas têm existência distinta da dos seus membros" (artigo 20 do CCB de 1916) e a criação de soluções de desconsideração ou de limitação da personalidade, quando este instituto fosse direcionado a desvios ilícitos, à abusividade funcional de estruturas personificadas, reconhecidas e sancionadas no ordenamento jurídico brasileiro. Mediante construções eminentemente jurisprudenciais, seguidas de profundos estudos doutrinários e paulatino acolhimento pelo direito positivo, a segunda opção consolidou-se na ciência jurídica do século XX. ${ }^{111}$

No direito brasileiro, desde o ensaio pioneiro de Rubens Requião ${ }^{112}$, são inúmeros os trabalhos monográficos sobre a

${ }^{110}$ Sobre o assunto, esclarece Marcia Carla Pereira Ribeiro: "Se no século XVIII a tônica estava no individualismo e liberalismo, destacando-se o princípio da legalidade, no atual século, sobretudo na sua segunda metade, o Direito vivencia a era dos fins e dos valores" (RIBEIRO, Márcia Carla Pereira. Sociedade de economia mista \& empresa privada: estrutura e função. Curitiba: Juruá, 1999, p.44).

${ }^{111}$ Em obra específica sobre o tema Guillermo Julio Borba esclarece: "La formulación de la doctrina del levantamiento del velo de la personería ha sido eminentemente de carácter judicial, y si bien es una doctrina que lleva muchos años de elaboración, hoy y más que nunca, es algo que tiene plena vigencia y debe contar con la mayor aceptación". (BORBA, Guillermo Julio. La persona jurídica y el corrimiento del velo societario. Buenos Aires: Abeledo-Perrot, 2000, p.29).

${ }^{112}$ REQUIÃO, Abuso de direito e fraude através da personalidade jurídica, p.12-24. 
desconsideração da pessoa jurídica. ${ }^{113}$ A experiência jurisprudencial é igualmente vasta e prescreve a desconsideração da pessoa jurídica em casos de encerramento irregular de sociedades personificadas, ${ }^{114}$ confusão patrimonial entre os bens do sócio e da pessoa jurídica, ${ }^{115}$ abuso de direito ${ }^{116}$ (como, por exemplo, em casos de grupo de sociedades ${ }^{117}$ ), fraude contra credores e fraude contra a execução, ${ }^{118}$ dentre outras hipóteses.

${ }^{113}$ Citem-se, sem prejuízo de tantos outros, os autores consultados, adiante indicados em ordem aleatória, RIBEIRO, Marcia Carla Pereira. A desconsideração da personalidade jurídica como forma de aplicação do princípio da preservação da empresa. Jurisprudência brasileira, cível e comércio, n. 196, p.87-92, 2002; ALVIM, Thereza. Aplicabilidade da teoria da desconsideração da pessoa jurídica no processo falimentar. Revista de processo. a. 22, n. 87, jul./set. 1997, p.211; MARINONI, Luiz Guilherme. Fraude. Configuração. Prova. Desconsideração da personalidade jurídica. Genesis - Revista de Direito Processual Civil. Curitiba, n.15, p. 143, jan/mar, 2000; JUSTEN FILHO, Desconsideração da personalidade societária no direito brasileiro, 1987; ALVES, Alexandre Ferreira. A desconsideração da personalidade jurídica e o direito do consumidor: um estudo de direito civil constitucional. In: TEPEDINO, Gustavo (Org). Problemas de direito constitucional. Rio de Janeiro: Renovar, 2001, p.243.

${ }^{114}$ RT 768/259; RT 511/199; RT 711/117; RT 747/269; RT 769/252; STJ. Recurso Especial n. ${ }^{\circ} 63.652-$ SP. Rel. Min. Barros Monteiro. DJ. 21.08.2000.

${ }^{115}$ RT 808/324; RT 713/129; TJDF. Apelação Cível n. 2000.01.1.100977-7. 4a turma Rel. Des. Sérgio Bittencourt, j. 18.03.2002.

116 STJ. Recurso especial n.325977-MG. 3a turma. Rel. Min. Carlos Alberto Menezes Direito. DJ. 27.11.2000.

117 STJ. Medida Cautelar n. 7.287-SP. 3a turma. Rel. Min. Carlos Alberto Menezes Direito. j. 18.11.03. STJ. Recurso ordinário em mandado de segurança $n$. 14.856-SP. 3a turma. Rel. Min. Carlos Alberto Menezes Direito. j. 11.03.03

${ }^{118}$ RT 819/245; RT 810/326; RT 673/160; RT 799/274; RT 792/318; RT 763/277; RT 657/120; STJ. Recurso especial n. 86502-SP. 4a turma. Rel. Min. Ruy Rosado de Aguiar Júnior. DJ. 26.08.1996; STJ. Recurso
A desconsideração da pessoa jurídica segue, entretanto, caracterizada como medida excepcional, ${ }^{119}$ dependente de prova circunstanciada $^{120}$ sobre os fatos que justifiquem a providência extrema, que não se há de confundir com a dissolução.

A legislação tem acolhido a teoria da desconsideração da pessoa jurídica, por vezes até mesmo ampliando seus horizontes, como no Código de Defesa do Consumidor (art. 28 da Lei n. $\left.{ }^{\circ} 8.075 / 90\right)$ e nas leis ambientais (especialmente, no art $4 .^{\circ}$ da Lei n. ${ }^{\circ}$ 9.605/98).

A teoria da desconsideração (disregard doctrine) ou da penetração (Durchgrifshaftung) da pessoa jurídica - por intermédio da qual ocorreria a ineficacização parcial da personificação para que a esfera jurídica dos sócios fosse alcançada - surgiu como uma construção jurisprudencial anglo-americana, depois alemã, e, por fim, universalizou-se, reavivando o debate sobre o conceito mesmo de pessoa jurídica. Na obra de J. Lamartine Corrêa de Oliveira ficara indubitável que as teses de desconsideração acabariam retomando os dois pontos antagônicos do debate doutrinário sobre a natureza da pessoa jurídica.

especial n. 252.759-SP. 3a turma. Rel. Min. Carlos Alberto Menezes Direito. DJ. 27.11.2000; Recurso ordinário em mandado de segurança n. 15.312-MG. 3a turma. Rel. Min. Carlos Alberto Menezes Direito, j. 20.05.03; STJ. Recurso especial n. 437.086-DF. 3a turma. Rel. Min. Carlos Alberto Menezes Direito. j. 5.12.02; STJ. Recurso especial n. 476.713-DF. 4a turma. Rel. Min. Sálvio de Figueiredo Teixeira. j. 20.03.2003; STJ. Recurso ordinário em mandado de segurança $n$. 12.873-SP. 4a turma. Rel. Min. Fernando Gonçalves. j. 02.12.2003; STJ. Recurso especial n. 370.068-GO. 3a turma. Min. Nancy Andrighi. j.16.10.03.

${ }^{119}$ RT 461/127; RT 761/283.

${ }^{120}$ RT 690/ 103; RT 771/258; RT 811/241; RT 809/269; STJ. Recurso especial n.256.292-MG. 4a turma. Rel. Min. Ruy Rosado de Aguiar. DJ. 25.09.2000. 
De um lado, a construção teórica norte-americana promove com facilidade a desconsideração da pessoa jurídica nas hipóteses de utilização disfuncional desse instituto, como decorrência lógica da adoção das construções ficcionistas. Se a pessoa jurídica é uma ficção criada pelo direito, fica fora de discussão que o próprio direito poderia desfazer essa ficção para coibir desonestidades. Segundo Klaus Unger, uma vez que para o direito norte-americano, em geral, "a pessoa jurídica seria apenas uma ficção imaginada por motivos técnicojurídicos, para que com isso determinadas finalidades, que a ordem jurídica não desaprova, pudessem ser atingidas", a operação de desconsideração seria facilitada pois "nem os imperativos da lógica nem os do Direito poderiam porém exigir do juiz a preservação dessa ficção, quando com isso pudessem ser justificadas desonestidades". ${ }^{121}$ Daí concluir Lamartine que haveria "especial ligação entre a doutrina do 'disregard' e a doutrina da ficção como tese explicativa em matéria de pessoa jurídica". ${ }^{122}$

Advirta-se, todavia, que assim como a teoria da ficção reverte em autêntico estatalismo para a constituição da pessoa jurídica (relembre-se, aqui, a ligação entre ficção e sistema de concessão da personalidade em Savigny ${ }^{123}$ ), a vinculação entre ficção e

${ }^{121}$ UNGER, Klaus. Die Inanspruchnahme des verdeckten Kapitalgebers. In: Konkurs-, Treuhand- und Schiedgerichtswesen, p.36, mar./1959. Apud CORRÊA DE OLIVEIRA, A dupla crise da pessoa jurídica, p.268.

${ }^{122}$ CORRÊA DE OLIVEIRA, A dupla crise da pessoa jurídica, p.268

${ }^{123}$ Ver nota de rodapé n.18, cf. SAVIGNY, Sistema del diritto romano attuale. trad. Vittorio Scialoja, p. 277. desconsideração da pessoa jurídica explicita o mesmo estatalismo para a repressão das situações de disfuncionalidade desse instituto. Isto, na aguda crítica de Josserand, poderia reengendrar obra de tirania e esterilização social inaceitável. ${ }^{124}$

Noutros ordenamentos mais afeitos à precisão conceitual, a crise de função acabou por denunciar a necessidade de valorização da realidade das instituições sociais para além das formas de personalidade jurídica. Citem-se, por exemplo, julgados dos tribunais alemães mencionados por Unger: "o juiz deve levar em conta as realidades da vida e o poder dos fatos mais do que as construções jurídicas"125.

J. Lamartine Corrêa de Oliveira, sempre fiel a seus pressupostos, proclamou que a crise da função da pessoa jurídica provém da desconformidade entre a realidade de algumas instituições perante os limites ontológicos e a fidelidade axiológica que esse instituto deve guardar em relação ao ordenamento jurídico: “A ordem jurídica só tem sentido quando orientada basicamente por determinados valores sem os quais ela não tem justificativa possível”; sendo assim, "a pessoa jurídica, realidade acidental e subordinada a esses valores reitores da ordem jurídica, existe em

${ }^{124}$ A assertiva assaz enérgica de Louis Josserand parece irrefutável: “l'arbitraire de l'Etat n'est pas un idéal à pursuivre; il ne faut pas que les pouvoirs publics puissent comprimer à leur guise le mouvement corporatif, associationnel et faire oeuvre de tyrannie, de stérilisation sociale" (JOSSERAND, Cours de droit civil positiffrançais, p.380).

${ }^{125}$ UNGER, Klaus. Die Inanspruchnahme des verdeckten Kapitalgebers. In: Konkurs-, Treuhandund Schiedgerichtswesen, p.33, mar./1959. Apud CORRÊA DE OLIVEIRA, A dupla crise da pessoa jurídica, p. 284). 
função de determinados fins, considerados humana e socialmente relevantes" 126 .

Sob esse prisma dinamizador, Lamartine desenvolveu sua compreensão precursora sobre a desconsideração da pessoa jurídica, o que vem circunstanciado em três pontos. Em primeiro lugar, há que se superar a concepção unitarista da pessoa jurídica: pelo fato de a pessoa jurídica não ser equivalente ao ser humano, sua realidade não é unívoca, mas diversificada em inúmeros e diferentes tipos de pessoas. Por essa razão, em alguns desses tipos (como, e.g., a sociedade unipessoal e os grupos de sociedade) a maior proximidade real entre os sócios e a pessoa jurídica facilitaria as operações de desconsideração, que seriam dificultadas noutras pessoas jurídicas em que houvesse um distanciamento maior entre os membros e as entidades (v.g., associações com inúmeros membros).

Em segundo lugar, não se podem confundir os casos de desconsideração da pessoa jurídica com as hipóteses legais de imputação de deveres a sujeitos diversos da pessoa jurídica ${ }^{127}$ ou com a dissolução coativa de pessoas jurídicas. A autêntica desconsideração da pessoa jurídica exige a suspensão de eficácia da personalidade jurídica para alcançar terceiros no que tange a certas e determinadas obrigações da pessoa jurídica. ${ }^{128}$ Nesse aspecto, a desconsideração da pessoa jurídica teria especial relevância no

${ }^{126}$ CORRÊA DE OLIVEIRA, A dupla crise da pessoa jurídica, p. 608.

127 CORRÊA DE OLIVEIRA, A dupla crise da pessoa jurídica, p.610.

${ }^{128}$ A diferenciação não é acolhida, em geral, pela jurisprudência. Cite-se, nesse sentido, RT 654/182; RT 660/181; STJ. Recurso especial n. 8.7110-RS. 2a turma. Rel. Min. Peçanha Martins. DJ. 17.12.1982. esquema subjetivista de Rudolf Serick que se entrelaça à idéia de abuso de direito.

Em terceiro e último lugar, deve-se buscar uma solução fiel ao realismo propugnado ao longo de toda a obra aqui analisada. J. Lamartine Corrêa de Oliveira resume o problema e a resposta:

se é em verdade uma outra pessoa que está a agir, utilizando a pessoa jurídica como escudo, e se é essa utilização da pessoa jurídica, fora de sua função, que está tornando possível o resultado contrário à lei, ao contrato, ou às coordenadas axiológicas (...) é necessário fazer com que a imputação se faça com predomínio da realidade sobre a aparência ${ }^{129}$.

Eis a dupla crise e a proposta de soluções mediante uma reaproximação do direito com a vida, com a realidade dos grupos intermediários entre o indivíduo e o Estado.

\section{RELER É PRECISO: A OBRA DO PROFESSOR J. LAMARTINE CORRÊA DE OLIVERA AQUI E AGORA}

No ano de 2005, completam-se dezesseis anos do aniversário de falecimento de J. Lamartine Corrêa de Oliveira; vinte e seis

${ }^{129}$ CORRÊA DE OLIVEIRA, A dupla crise da pessoa jurídica, p.613. Para minimizar os efeitos da crise de função, o autor propôs nova redação ao Projeto de Código Civil: “Art. 50. Quando a pessoa jurídica tiver sua autonomia subjetiva utilizada como instrumento destinado a fraudar a lei, ou as obrigações contratuais, ou a causar prejuízos a terceiros, poderá o juiz, no caso concreto, suspender a vigência do princípio jurídico que lhe reconhece personalidade distinta da de seus sócios ou dirigentes, fazendo responder pelas consequiências patrimoniais dos atos praticados, conjuntamente com os da pessoa jurídica, os bens do sócio, do controlador ou administrador, de direito ou fato, a que sejam imputáveis os atos fraudulentos ou lesivos ou que por eles sejam beneficiados" (CORRÊA DE OLIVEIRA; WALD, Emendas ao projeto de código civil, p.30). 
anos da publicação de sua obra sobre a dupla crise da pessoa jurídica e trinta e três anos da apresentação de sua tese sobre o conceito de pessoa jurídica.

De lá para cá, muita água passou por debaixo da ponte e nem sempre água límpida. No Brasil, assistiu-se à redemocratização e à promulgação da Constituição de 1988, cujo texto foi objeto de preocupação e estudos do privatista J. Lamartine Corrêa de Oliveira, já despontando alguns indicativos da metodologia posteriormente consagrada como constitucionalização do direito civil ${ }^{130}$.

A legislação de direito privado foi sensivelmente alterada, seja por intermédio de inúmeros microssistemas legislativos como o código de defesa do consumidor (Lei n. $\left.{ }^{\circ} 8.078 / 90\right)$ e a lei de locação de imóveis urbanos (Lei n. $\left.{ }^{\circ} 8.245 / 91\right)$-, seja pelo advento do novo Código Civil (Lei n. ${ }^{\circ}$ 10.406/02), cujo projeto foi acompanhado e criticado por J. Lamartine Corrêa de Oliveira. ${ }^{131}$

O mundo também mudou muito e muito mais do que este novo Código. A queda do muro de Berlim (1989), a onda neoliberal e a globalização econômica, a re-organização do mundo europeu em comunidade e a revolução nas comunicações pelo advento da internet, são sinais, e apenas sinais.

Um jovem estudante que recebesse por indicação a leitura da vasta produção teórica

${ }^{130}$ Sobre o assunto, cf. FACHIN, Luiz Edson. A "Reconstitucionalização" do Direito Civil brasileiro: lei nova e velhos problemas à luz de dez desafios. Revista Jurídica, São Paulo, v.52, n.324, p.16-19, out.2004; TEPEDINO, Gustavo. Premissas Metodológicas para a constitucionalização do Direito Civil. In: Temas de Direito Civil. Rio de Janeiro: Renovar, 1999, p.1.

131 CORRÊA DE OLIVEIRA, J. Lamartine. O código civil projetado. Revista da OAB: conselho federal. Janeiro a abril de 1984. de J. Lamartine Corrêa de Oliveira poderia se perguntar: o humanismo e o personalismo ético como vetores teóricos permanentes, o combate ferrenho ao reducionismo economicista, a luta intransigente por uma universidade pública, gratuita e de qualidade e a corrosiva crítica à arbitrariedade estatal em regime ditatorial ainda poderiam ensinar? Lindes decisivamente marcantes no pensamento deste autor ainda serviriam para compreender o universo contemporâneo, fragmentado pela chamada pós-modernidade, tão fugidia como tudo o que se diz 'pós'?

Em outras palavras: por que reler a obra de J. Lamartine Corrêa de Oliveira hoje, em um País e num mundo tão diferente daquele que fora há vinte e tantos anos?

A obra de J. Lamartine Corrêa de Oliveira é uma lição de coerência metodológica e existencial. Ainda que não afeito a dogmatismos, seu pensamento está longe de recair num relativismo estéril. Nos seus livros, ensaios monográficos e discursos, são explícitos os seus pressupostos filosóficos como premissas indispensáveis para suas conclusões. Como lição de resistência, Lamartine avisara seus alunos: “Aceitarei o risco de ser um homem que crê no primado do espírito. Sou fiel à minha vocação jurídica mas só sou capaz de entendê-la à luz de um compromisso com a realidade social, inspirado por uma orientação filosófica"132.

Lamartine, deliberadamente, expôs-se ao mundo, sem medo de que seus alicerces fossem abalados pelos críticos, podendo-se ouvir em seus discursos a citação de M. Jourdain -

${ }^{132}$ CORRÊA DE OLIVEIRA, Lição de resistência, 1965. 
"Chassez la philosophie, et elle réviendra au galop" -, os problemas de definição filosófica não podem ser escamoteados ${ }^{133}$. Nem mais antes do que agora.

$\mathrm{Na}$ ordem nacional e mundial as reflexões sobre a pessoa jurídica voltaram à tona. No Brasil, a constitucionalização do direito civil garante que a liberdade associativa (art. 5. ${ }^{\circ}$, incisos XVII, XVIII, XIX, XX e XXI, da C.R.), em um Estado democrático de direito fundamentado no pluralismo político (art. 1. ${ }^{\circ}$, inc.V, da C.R.) revigora o papel dos grupos intermediários, personificados ou não, para a construção de uma sociedade livre, justa e solidária (art. 1. ${ }^{\circ}$, inc.I, da C.R.).

A dignidade da pessoa humana, erigida como fundamento da República (art. 1. ${ }^{\circ}$, inc.III, da C.R.), ultrapassa a perspectiva abstrata e individualista, ${ }^{134}$ devendo ser contextualizada no sentido histórico e social que muitas vezes se concretiza nos grupos intermediários: as associações de base, as associações ambientais e de proteção ao consumidor, as cooperativas de trabalhadores e o movimento dos trabalhadores sem-terra, dentre tantas outras organizações populares, são realidades coletivas que não podem ser compreendidas pelo ficcionismo ou pelo normativismo, pretensamente adstritos à pura racionalidade tecnicista. Negar realidade eis a palavra-chave da obra de Lamartine -

${ }^{133}$ CORRÊA DE OLIVEIRA, Lição de resistência, 1965.

${ }^{134}$ Sobre o assunto, cf. FACHIN, Luiz Edson; RUZYK, Carlos Eduardo Pianovski. Direitos fundamentais, dignidade da pessoa humana e o novo código civil: uma análise crítica. In: SARLET, Ingo Wolfgang. Constituição, direitos fundamentais $e$ direito privado. Porto Alegre: Livraria do advogado, 2003, p.87. a essas entidades, reconhecidas ou não pela lei, implica afastamento das diretrizes constitucionais.

O chamado terceiro setor - ressalvadas as críticas pela vinculação tatuada de neoliberalismo -, procura desenhar uma alternativa entre o setor do Estado e o setor do mercado, amealhando recursos e poder político que não podem ser ignorados pelo direito. ${ }^{135}$ A recente alteração da legislação italiana sobre as pessoas jurídicas (D.PR. 10.02.2000, n. 361), por exemplo, veio predestinada a facilitar o reconhecimento destas organizações, reduzindo as diferenças entre os entes personificados e os não personificados à força da realidade desses agrupamentos em que primacialmente irá articular-se a sociedade democrática do tempo vigente ${ }^{136}$.

Em outras palavras: a crise de estrutura, denunciada por J. Lamartine Corrêa de Oliveira, está na pauta urgente do cotidiano. Do mesmo modo, a crise de função tem apresentado novos contornos, inovações legislativas que procuram superar a sintomática da crise pela concretização dos valores do ordenamento jurídico.

Todas essas questões fazem com que o pensamento do professor e advogado J. Lamartine Corrêa de Oliveira mostre-se supinamente atual, impondo-se a sua releitura

${ }^{135}$ HERZLINGER, Regina E. Can public trust in nonprofits and governments be restored? Harvard business review on nonprofits. Boston: Harvard publishing, 1999, p.11; COELHO, Simone de Castro Tavares. Terceiro setor: um estudo comparado entre Brasil e Estados Unidos. 2.ed. São Paulo: Senac, 2002, p.81.

${ }^{136}$ Sobre o assunto, cf. BASILE, Massimo. Le persone giuridiche. Milano: Giuffrè, 2003, p.25 e DE GIORGI, Maria Vita. et alli. Il riconoscimento delle persone giuridiche. Milano: IPSOA, 2001. 
para enfrentar a questão da pessoa jurídica no século XXI, vez que, se as circunstâncias nacionais e mundiais foram drasticamente alteradas, os problemas de exclusão social e de realização democrática reapresentam-se ininterrupta e crescentemente.

A reverberação de seu discurso $A$ véspera dos bárbaros, proferido aos bacharelandos da UFPR - Turma Des. Hugo Simas, como paraninfo, ainda irradia tons de premência e de civilidade, de apelo e de reconstrução:

Na tarefa de preparação de um nôvo Brasil, há imenso lugar para os juristas. se é necessário construir nova estrutura social e econômica, a ela deverá corresponder nova estrutura jurídica (...) Se a Economia grandemente condiciona o Direito, êste em troca pode alterá-la e preparar seu evolver.

A tarefa que vos indiquei é trabalho de juristas - não de leguleios. Leguleios julgam lei tudo o que está escrito e promulgado pelo Poder Público e, formados pelas nocivas tendências do positivismo jurídico, suas convicções meramente formais não são suficientemente fortes para impedí-los de reconhecer validade e vigência até a tentativa de cortar a liberdade de exercício profissional por parte de cidadãos postos em desgraça política.

O jurista, porém, vê mais alto, pois sabe que acima do Direito Positivo estão as normas que a consciência humana descobre na natureza das coisas. Percebe que o gradativo refinamento da consciência humana - Direito Natural de conteúdo progressivo - é cada vez mais exigente quanto à adequação do direito Positivo aos ideais humanos de liberdade, justiça, igualdade e fraternidade. ${ }^{137}$

Em três palavras: coragem, cidadania, dignidade.

137 CORRÊA DE OLIVEIRA, J. Lamartine. A véspera dos bárbaros. Discurso de paraninfo proferido em 8 de março de 1968 aos bacharelandos da turma "Des. Hugo Simas". Centro Acadêmico Hugo Simas, 1968 (mimeo).

\section{BIBLIOGRAFIA}

ALVES, A. F. A desconsideração da personalidade jurídica e o direito do consumidor: um estudo de direito civil constitucional. In: TEPEDINO, G. (Org.). Problemas de direito constitucional. Rio de Janeiro: Renovar, 2001.

ALVIM, T. Aplicabilidade da teoria da desconsideração da pessoa jurídica no processo falimentar. Revista de processo. a. 22, n. 87, jul./set. 1997, p.211

BAKER, E. Translator's introduction. In: GIERKE, O. V. Natural law and the theory of society 1500 to 1800. trad. Ernest Barker. Boston: Beacon Press, 1957.

BARROS MONTEIRO, W. de. Curso de direito civil: parte geral. São Paulo: Saraiva, 1960.

BASILE, M. Le persone giuridiche. Milano: Giuffrè, 2003.

BERNARDES DE MELLO, Marcos. Teoria do fato jurídico: plano da eficácia. São Paulo: Saraiva, 2003

BEVILAQUA, C. O projecto de código civil e o Sr. Dr. Coelho Rodrigues. In: Projecto do codigo civil brazileiro. Rio de Janeiro: Imprensa nacional, 1902.

BEVILAQUA, C. Teoria geral do direito civil. Rio de Janeiro: Editora Rio e Livraria Francisco Alves, 1975.

BIANCA, M. Diritto civile. v. I. 2.ed. Milano: Giuffrè, 2002.

BORBA, G. J. La persona jurídica y el corrimiento del velo societario. Buenos Aires: Abeledo-Perrot, 2000.

CARTAXO, E. G. As pessoas jurídicas em suas origens romanas. Curitiba: Empreza Gráfica Paranaense, 1943.

CARVALHO SANTOS, J. M. de. Código civil brasileiro interpretado. v. I. 4.ed.

Rio de Janeiro: Freitas Bastos, 1950.

CARVALHO, O. de. A teoria geral da relação jurídica: seu sentido e limites. 2.ed. Coimbra: Centelha, 1981. 
CARVALHO, O. de. Teoria geral do direito civil. Sumários desenvolvidos para uso dos alunos do 2. ${ }^{\circ}$ ano. Coimbra: Centelha, 1981.

CLÉMENS, R. Personnalité morale et personnalité juridique. Paris: Sirey, 1935.

COELHO, S. de C. T. Terceiro setor: um estudo comparado entre Brasil e Estados Unidos. 2.ed. São Paulo: Senac, 2002.

COMPARATO, F. K. O poder de controle na sociedade anônima. São Paulo: Saraiva, 1976.

CORRÊA DE OLIVEIRA, J. L. A dupla crise da pessoa jurídica. São Paulo: Saraiva, 1979.

CORRÊA DE OLIVEIRA, J. L. A função social do advogado e a crise do ensino jurídico. In: semana do advogado (7 a 11 de agosto de 1972). Ordem dos advogados do Brasil - Seção do Paraná, 1972.

CORRÊA DE OLIVEIRA, J. L. A justiça social e o direito privado brasileiro: denúncia de uma 'opção pelos ricos'. Tese n. 19. In: Conferência nacional da ordem dos advogados do Brasil. Rio de Janeiro: Folha Carioca Editora Ltda., 1982.

CORRÊA DE OLIVEIRA, J. L. A parte geral do anteprojeto de código civil. Revista dos Tribunais. a. 63, v. 466, ago./1974.

CORRÊA DE OLIVEIRA, J. L. A teoria das pessoas no esboço de Teixeira de Freitas. Superação e permanência. In: SCHIPANI, S. A. Teixeira de Freitas e Il diritto latinoamericano. Padova: Cedam, 1988.

CORRÊA DE OLIVEIRA, J. L. A véspera dos bárbaros. Discurso de paraninfo proferido em 8 de março de 1968 aos bacharelandos da turma "Des. Hugo Simas". Centro Acadêmico Hugo Simas, 1968 (mimeo).

CORRÊA DE OLIVEIRA, J. L. Conceito de pessoa jurídica. Tese apresentada à Faculdade de Direito da Universidade Federal do Paraná para concurso de livre docência de Direito Civil. Curitiba, 1962 (mimeo).

CORRÊA DE OLIVEIRA, J. L. Intervenção do estado no direito contratual. Curitiba, 1962.

CORRÊA DE OLIVEIRA, J. L. Lição de resistência. Discurso de paraninfo aos Bacharéis em Direito de 1965 da Universidade Federal do Paraná, turma Ministro Alvaro Ribeiro da Costa (тітео).

CORRÊA DE OLIVEIRA, J. L. Notícias sobre a parte geral do novo código civil português. Revista da Faculdade de Direito da UFPR. Curitiba, a. 12, n. 12, 1969.

CORRÊA DE OLIVEIRA, J. L. O código civil projetado. Revista da OAB: conselho federal. jan./abr. 1984.

CORRÊA DE OLIVEIRA, J. L. Personalidade jurídica da sociedade irregular. Revista da Faculdade de Direito da UFPR. Curitiba, a. 10, n. 10, 1964-1967.

CORRÊA DE OLIVEIRA, J. L.; MUNIZ, F. J. F. Curso de direito de família. 2.ed. Curitiba: Juruá, 1998.

CORRÊA DE OLIVEIRA, J. L.; MUNIZ, F. J. F. O Estado de Direito e os direitos da personalidade. Revista dos tribunais. a. 69 , v. 532 , fev./1980.

CORRÊA DE OLIVEIRA, J. L.; MUNIZ, F. J. F.; APPEL, E. J. Cultura, ensino e universidade: contribuição da UFPR ao debate constitucional. Curitiba: UFPR, 1986.

CORRÊA DE OLIVEIRA, J. L.; WALD, A. Emendas ao projeto de código civil. Rio de Janeiro: Ordem dos Advogados do Brasil, 1984.

D'ALESSANDRO, F. Persone giuridiche e analisi del linguaggio. Padova: Cedam, 1989.

DANTAS, S. T. Programa de direito civil. Rio de Janeiro: Editora Rio, 1979.

DE GIORGI, M. V. et al. Il riconoscimento delle persone giuridiche. Milano: IPSOA, 2001.

DELOS, J,-T. La théorie de l'Institution. La solution réaliste du problème de la personnalitè morale et le droit à fondement objectif. Archives de philosophie du droit et de sociologie juridique. n. 1-2, Cahier double, Recueil Sirey, 1931.

DÍEZ-PICAZO, L.; GULLÓN, A. Instituciones de derecho civil. 2.ed. Madrid: Tecnos, 2000.

DUGUIT, L. Traité de droit constitutionel. 12. ed. v. V. Paris: Ancieme Librairie, 1925. 
ENNECCERUS, L.; NIPPERDEYM

H. C. Derecho civil (parte general). In: ENNECCERUS-KIPP-WOLF. Tratado de derecho civil. v. I. Barcelona: Bosch, 1954.

ENPC LATTS, G. J. Les associations, L'Etat et la théorie de l'institution de Maurice Hauriou. Les annales de la recherche urbaine. n. 89, jun./2001.

FACHIN, L. E. A "Reconstitucionalização" do Direito Civil brasileiro: lei nova e velhos problemas à luz de dez desafios. Revista Jurídica, São Paulo, v.52, n.324, p.16-19, out.2004.

FACHIN, L. E. Teoria crítica do Direito Civil. Rio de Janeiro: Renovar, 2000.

FACHIN, L. E.; RUZYK, C. E. P. Direitos fundamentais, dignidade da pessoa humana e o novo código civil: uma análise crítica. In: SARLET, I. W. Constituição, direitos fundamentais e direito privado. Porto Alegre: Livraria do advogado, 2003.

FERRARA, F. Teoria delle persone giuridiche. 2.ed. riveduta. Napoli: Marghieri, 1923.

GALGANO, F. Struttura logica e contenuto normativo del concetto di persona giuridica. Rivista di diritto civile. a. XI, n. 6, Padova, Cedam, nov-dic, 1965.

GENY, F. Science et technique en droit privé positif. v. III. Paris: Sirey, 1921.

GIERKE, O. V. Associations and law: the classical and early christian stages. trad. George Heiman. Toronto: University of toronto press, 1977.

GIERKE, O. V. Natural law and the theory of society 1500 to 1800. trad. Ernest Barker. Boston: Beacon Press, 1957.

GIERKE, O. V. Political theories of the middle age. trad. Frederic William Maitland. Boston: Beacon Press, 1958.

GOMES, O. Introdução ao direito civil. 6.ed. Rio de Janeiro: Forense, 1979.

GONÇALVES NETO, A. de A. Lições de direito societário. São Paulo: Juarez de Oliveira, 2002.
GONÇALVES, C. R. Direito civil brasileiro: parte geral. v. I. São Paulo: Saraiva, 2003.

GRESSAYE, J. B. de la. The sociological theory of the institution and french juristic thought. In: BRODERIK, A. The french institutionalists: Maurice Hauriou, Georges Renard, Joseph T. Delos. trad. Mary Wlling. Massachusetts: Harvard University Press, 1970.

GURVITCH, G. Les idées maitresses de Maurice Hauriou. Archives de philosophie du droit et de sociologie juridique. n. 1-2, Cahier double, Recueil Sirey, 1931.

HAURIOU, M. Teoria dell'istituzione e della fondazione. Milano: Giuffrè, 1967.

HECK, P. Interpretação da lei e jurisprudência dos interesses. trad. José Osório. São Paulo: Saraiva, 1948.

HERZLINGER, R. E. Can public trust in nonprofits and governments be restored? Harvard business review on nonprofits. Boston: Harvard publishing, 1999.

IHERING, R. Von. El espíritu del Derecho Romano. t.I. Granada : Comares, 1998.

JOSSERAND, L. Cours de droit civil positif français. 3.ed. Paris: Sirey, 1938.

JUSTEN FILHO, M. Desconsideração da personalidade societária no direito brasileiro. São Paulo: Revista dos Tribunais, 1987.

KELSEN, H. Teoria pura do direito. 4.ed. Trad. João Baptista Machado. Coimbra: Armênio Amado, 1976.

LACERDA DE ALMEIDA, F. de P. Das pessoas jurídicas: ensaio de uma theoria. Rio de Janeiro: Revista dos Tribunais, 1905.

LARENZ, K. Derecho civil: parte general. Madrid: Editorial Revista de Derecho Privado, 1978.

LARENZ, K. Metodologia da ciência do direito. Lisboa: Calouste Gulbekian, 1997.

LISBOA, R. S. Manual de direito civil. 3.ed. São Paulo: Revista dos Tribunais, 2003.

MARINONI, L. G. Fraude. Configuração. Prova. Desconsideração da personalidade jurídica. Genesis - Revista de Direito Processual Civil. Curitiba, n.15, p. 143, jan./mar. 2000 
NICOLÓ, A. M. P. La persona giuridica in diritto canonico. In: PEPPE, L. (Org.). Persone giuridiche e storia del diritto. Torino: Giapichelli, 2004.

ORESTANO, R. Il <problema delle persone giuridiche $>$ in diritto romano. Torino: Giappichelli, 1968.

PEREIRA, C. M. da S. Instituições de direito civil. 5.ed. Rio de Janeiro: Forense, 1976.

POMBO, E. L. Orientaciones sobre el concepto y el método del derecho civil. Buenos Aires: Rubinzal Culzoni, 2002.

PONTES DE MIRANDA, F. C. Comentários ao Código de Processo Civil. Rio de Janeiro: Forense, 1973.

PONTES DE MIRANDA, F. C. Tratado de Direito Privado. v. I. Rio de Janeiro: Borsoi, 1954.

RENARD, G. Les degrés de l'existence institutionnelle. In: La théorie de l'institution: essai d'ontologie juridique. Paris: Sirey, 1930.

REQUIÃO, R. Abuso de direito e fraude através da personalidade jurídica. Revista dos Tribunais. a. 58 , v. 410 , dez./1969.

RODRIGUES, S. Direito Civil. v. I. São Paulo: Max Limonad, 1962.

ROMANO, S. L'ordinamento giuridico. Firenze: Sansoni, 1951.

ROONEY, M. T. Introduction. In: BRODERIK, A. The french institutionalists: Maurice Hauriou, Georges Renard, Joseph T. Delos. trad. Mary Wlling. Massachusetts : Harvard University Press, 1970.
ROSSEL, V.; MENTHA, F.-H. Manuel du droit civil suisse. Lausanne/Genève: Payot, 199-.

SAVIGNY, F. C. Di. Sistema del diritto romano attuale. trad. Vittorio Scialoja. v. II. Torino: Unione tipografico editrice, 1888.

TEPEDINO, G. Premissas Metodológicas para a constitucionalização do Direito Civil. In: Temas de Direito Civil. Rio de Janeiro: Renovar, 1999.

TOBEÑAS, J. C. Derecho civil Español. 8.ed. Madrid: Instituto Editorial Reus, 1952.

TUOR, P. Le code civil suisse. 2.ed française d'apres la 5a édition allemande par Henri Deschenaux. Zurich: Éditions Polygraphiques, 1950.

VAREILLES-SOMMIÈRES, M. De. Les personnes morales. Paris: LGDJ, 1919.

VELGE, H. Associations et fondations en Belgique. Bruxelles: Bruylant, 1942.

VENOSA, S. de S. Direito civil: parte geral. São Paulo: Atlas, 2003.

WIEACKER, F. História do direito privado moderno. 2. ed. Lisboa: Calouste Gulbekian, 1993.

ZATTI, P. Persona giuridica e soggettività. Padova: Cedam, 1975. 